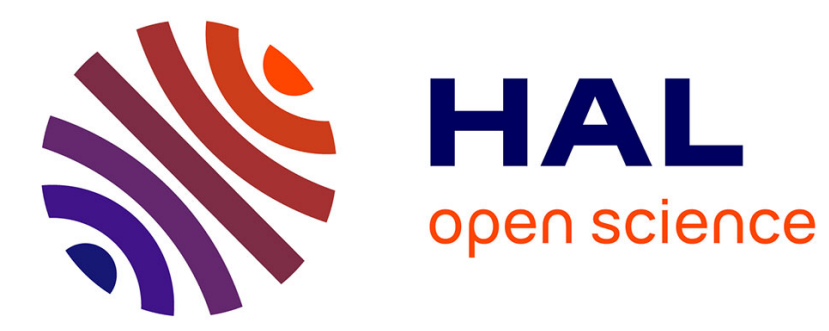

\title{
Greenhouse gases and ammonia emissions from organic mixed crop-dairy systems: a critical review of mitigation options
}

S. M. Novak, J.L. Fiorelli

\section{- To cite this version:}

S. M. Novak, J.L. Fiorelli. Greenhouse gases and ammonia emissions from organic mixed crop-dairy systems: a critical review of mitigation options. Agronomy for Sustainable Development, 2010, 30 (2), pp.215-236. 10.1051/agro/2009031 . hal-00886479

\section{HAL Id: hal-00886479 \\ https://hal.science/hal-00886479}

Submitted on 1 Jan 2010

HAL is a multi-disciplinary open access archive for the deposit and dissemination of scientific research documents, whether they are published or not. The documents may come from teaching and research institutions in France or abroad, or from public or private research centers.
L'archive ouverte pluridisciplinaire HAL, est destinée au dépôt et à la diffusion de documents scientifiques de niveau recherche, publiés ou non, émanant des établissements d'enseignement et de recherche français ou étrangers, des laboratoires publics ou privés.

$$
\text { Copyright }
$$




\title{
Greenhouse gases and ammonia emissions from organic mixed crop-dairy systems: a critical review of mitigation options
}

\author{
S.M. NOVAK ${ }^{1,2 *}$, J.L. FIORELLI ${ }^{1}$ \\ ${ }^{1}$ INRA-SAD, UR 055, 88500 Mirecourt, France \\ ${ }^{2}$ SOLPHY, La Grennery, 73670 Entremont-le-Vieux, France
}

(Accepted 3 August 2009)

\begin{abstract}
Dairy production systems represent a significant source of air pollutants such as greenhouse gases (GHG), that increase global warming, and ammonia $\left(\mathrm{NH}_{3}\right)$, that leads to eutrophication and acidification of natural ecosystems. Greenhouse gases and ammonia are emitted both by conventional and organic dairy systems. Several studies have already been conducted to design practices that reduce greenhouse gas and ammonia emissions from dairy systems. However, those studies did not consider options specifically applied to organic farming, as well as the multiple trade-offs occurring between these air pollutants. This article reviews agricultural practices that mitigate greenhouse gas and ammonia emissions. Those practices can be applied to the most common organic dairy systems in northern Europe such as organic mixed crop-dairy systems. The following major points of mitigation options for animal production, crop production and grasslands are discussed. Animal production: the most promising options for reducing greenhouse gas emissions at the livestock management level involve either the improvement of animal production through dietary changes and genetic improvement or the reduction of the replacement rate. The control of the protein intake of animals is an effective means to reduce gaseous emissions of nitrogen, but it is difficult to implement in organic dairy farming systems. Considering the manure handling chain, mitigation options involve housing, storage and application. For housing, an increase in the amounts of straw used for bedding reduces $\mathrm{NH}_{3}$ emissions, while the limitation of $\mathrm{CH}_{4}$ emissions from deep litter is achieved by avoiding anaerobic conditions. During the storage of solid manure, composting could be an efficient mitigation option, depending on its management. Addition of straw to solid manure was shown to reduce $\mathrm{CH}_{4}$ and $\mathrm{N}_{2} \mathrm{O}$ emissions from the manure heaps. During the storage of liquid manure, emptying the slurry store before late spring is an efficient mitigation option to limit both $\mathrm{CH}_{4}$ and $\mathrm{NH}_{3}$ emissions. Addition of a wooden cover also reduces these emissions more efficiently than a natural surface crust alone, but may increase $\mathrm{N}_{2} \mathrm{O}$ emissions. Anaerobic digestion is the most promising way to reduce the overall greenhouse gas emissions from storage and land spreading, without increasing $\mathrm{NH}_{3}$ emissions. At the application stage, $\mathrm{NH}_{3}$ emissions may be reduced by spreading manure during the coolest part of the day, incorporating it quickly and in narrow bands. Crop production: the mitigation options for crop production focus on limiting $\mathrm{CO}_{2}$ and $\mathrm{N}_{2} \mathrm{O}$ emissions. The introduction of perennial crops or temporary leys of longer duration are promising options to limit $\mathrm{CO}_{2}$ emissions by storing carbon in plants or soils. Reduced tillage or no tillage as well as the incorporation of crop residues also favour carbon sequestration in soils, but these practices may enhance $\mathrm{N}_{2} \mathrm{O}$ emissions. Besides, the improvement of crop N-use efficiency through effective management of manure and slurry, by growing catch crops or by delaying the ploughing of leys, is of prime importance to reduce $\mathrm{N}_{2} \mathrm{O}$ emissions. Grassland: concerning grassland and grazing management, permanent conversion from arable to grassland provides high soil carbon sequestration while increasing or decreasing the livestock density seems not to be an appropriate mitigation option. From the study of the multiple interrelations between gases and between farm compartments, the following mitigation options are advised for organic mixed crop-dairy systems: (1) actions for increasing energy efficiency or fuel savings because they are beneficial in any case, (2) techniques improving efficiency of $\mathrm{N}$ management at field and farm levels because they affect not only $\mathrm{N}_{2} \mathrm{O}$ and $\mathrm{NH}_{3}$ emissions, but also nitrate leaching, and (3) biogas production through anaerobic digestion of manure because it is a promising efficient method to mitigate greenhouse gas emissions, even if the profitability of this expensive investment needs to be carefully studied. Finally, the way the farmer implements the mitigation options, i.e. his practices, will be a determining factor in the reduction of greenhouse gas and $\mathrm{NH}_{3}$ emissions.
\end{abstract}

agriculture / greenhouse gas / ammonia / abatement / mixed crop-dairy systems / organic / livestock / manure / grassland / carbon storage / soil carbon sequestration

\section{INTRODUCTION}

There is currently a move towards more sustainable farming systems. One of the aims of sustainable agriculture is to

* Corresponding author: solphy@gmail.com establish environmentally-friendly production by limiting the adverse effects of agricultural activities on all the components of the environment. Regarding the atmosphere, agricultural activities may be a significant source of two major air pollutants: greenhouse gases (GHG), which contribute to global warming (IPCC, 2007), and ammonia $\left(\mathrm{NH}_{3}\right)$, which can lead to 

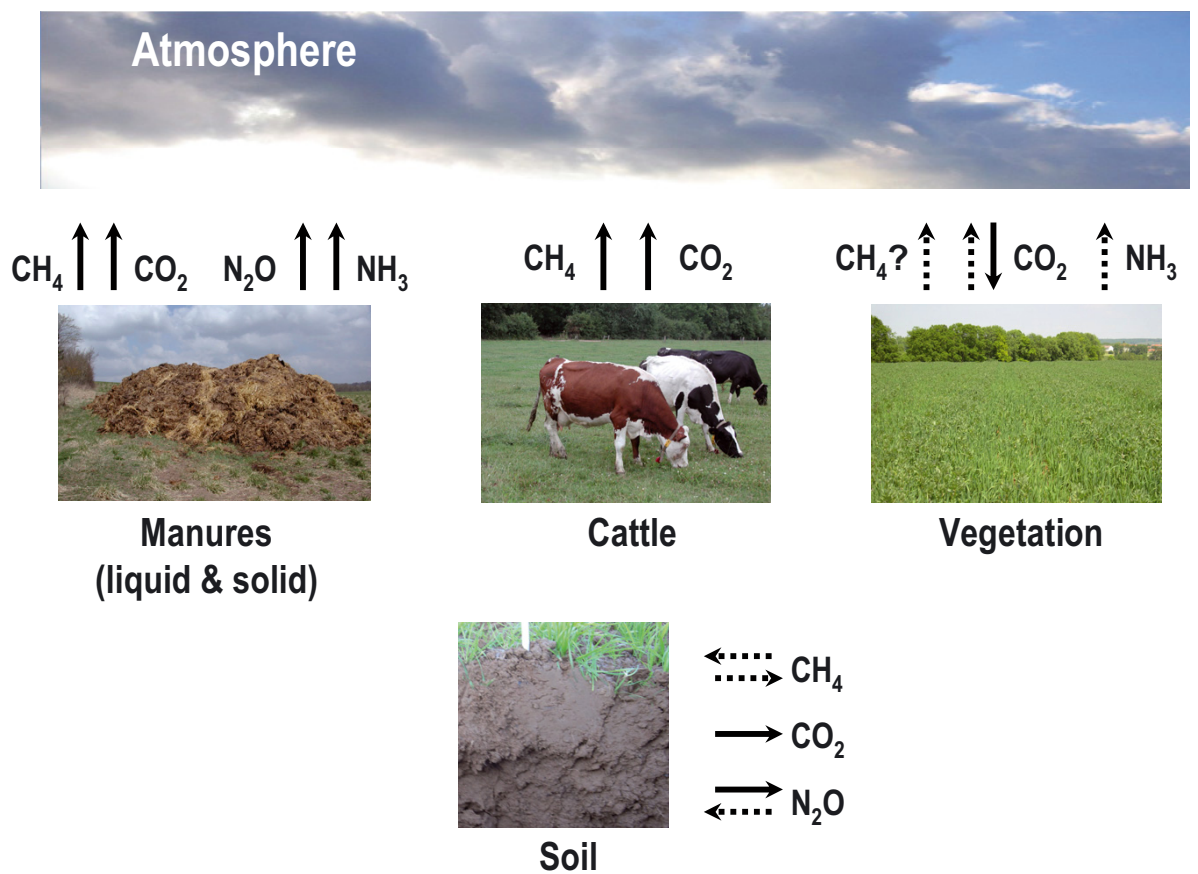

Figure 1. Greenhouse gas and ammonia fluxes in the main compartments of a mixed crop-dairy system (adapted from Soussana et al., 2004). Broken arrows indicate small fluxes. Emissions from cattle excreta are indicated in the compartment "manures". Photos by D. Foissy, INRA Mirecourt.

eutrophication and acidification of natural ecosystems (Ferm, 1998). Livestock production has recently been questioned because of its environmental damage, particularly in terms of climate change and air pollution (Steinfeld et al., 2006). Figure 1 summarises the GHG and $\mathrm{NH}_{3}$ fluxes of a mixed crop-dairy system.

Dairy production systems represent the largest agricultural source of the greenhouse gases methane $\left(\mathrm{CH}_{4}\right)$ and nitrous oxide $\left(\mathrm{N}_{2} \mathrm{O}\right)$ in Europe (Weiske et al., 2006). In dairy husbandry, methane is mainly produced from enteric fermentation in the rumen of cows - approximately $80 \%$ - and to a lesser extent by cattle manures (Monteny et al., 2006). Agricultural soils are a sink for methane rather than a source, consumption rates of atmospheric methane in soils being very low in European soil and climatic conditions (Le Mer and Roger, 2001; Oenema et al., 2001). Keppler et al. (2006) recently reported $\mathrm{CH}_{4}$ emissions by plant tissues under aerobic conditions, but these emissions seem not to significantly affect the $\mathrm{CH}_{4}$ budget of grazed grasslands (Allard et al., 2007). $\mathrm{N}_{2} \mathrm{O}$ emissions are mainly derived from $\mathrm{N}$ inputs to agricultural land, i.e. from chemical fertilisers, manure, urine deposited by grazing animals, leguminous crops and crop residues, and from animal houses, i.e. from deep litter systems and solid manure heaps (Chadwick et al., 1999; Monteny et al., 2006; Petersen et al., 2006). In certain conditions, soils can also be a sink for $\mathrm{N}_{2} \mathrm{O}$, but the factors regulating $\mathrm{N}_{2} \mathrm{O}$ consumption are not yet well understood (Chapuis-Lardy et al., 2007).

Carbon dioxide is another biogenic greenhouse gas playing a significant role in anthropogenic global warming. In dairy farming its major sources are soil and cattle. In soils, carbon dioxide is mainly released by microbial decay of plant litter and soil organic matter, and root respiration (Bahn et al., 2006). Cattle emit $\mathrm{CO}_{2}$ through the respiration of organic carbon from ingested grass or fodder. However, this short-cycling carbon is generally seen as not relevant for the greenhouse effect, because it is assumed that carbon dioxide emissions have been fixed by plants through photosynthetic activity earlier in the farm cycle and thus make no net contribution to global warming (Schils et al., 2005). Soils can also act as a sink for $\mathrm{CO}_{2}$; the $\mathrm{CO}_{2}$ fixed in plant biomass through photosynthesis can be stored in the soil as organic $\mathrm{C}$ by converting plant residues into soil organic matter after being returned to the soil. Root systems also make a significant contribution to soil $\mathrm{C}$ inputs through rhizodeposition (Rees et al., 2005). If the input of $\mathrm{C}$ into the soil is greater than its losses as $\mathrm{CO}_{2}, \mathrm{C}$ is stored in the soil.

In addition to their effect on global warming, agricultural activities and particularly livestock farming are the main source of atmospheric ammonia, around 50\% of European ammonia emissions coming from cattle production (Ferm, 1998). In dairy farms, losses of $\mathrm{NH}_{3}$ occur during slurry application, housing, slurry storage, grazing, fertiliser application and from crops, in descending order of importance (Bussink and Oenema, 1998). After deposition on land, ammonia can increase acidification and nutrient-N enrichment of sensitive habitats (Sutton et al., 1993). In addition, $\mathrm{NH}_{3}$ reacts with atmospheric acids to form ammonium $\left(\mathrm{NH}_{4}^{+}\right)$-containing aerosol, which may both directly and indirectly affect light scattering and global radiative forcing (Sutton et al., 2001), and which is likely to threaten human health in Europe (WHO, 


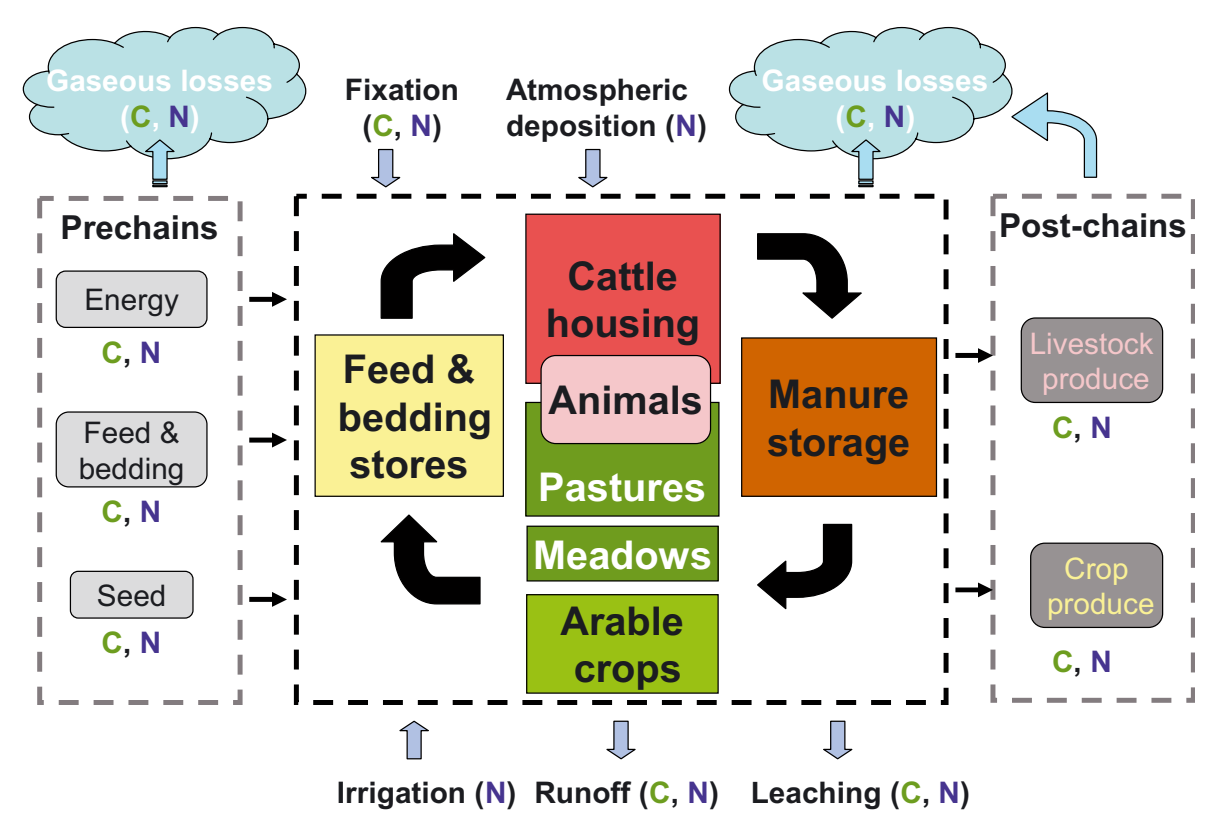

Figure 2. Carbon and nitrogen flows in and out of a mixed crop-dairy system and between its main compartments. Gaseous losses from pre- and post-chains are outlined. Adapted from Olesen et al. (2006).

2004). Furthermore, ammonia is an indirect source of $\mathrm{N}_{2} \mathrm{O}$ : Mosier et al. (1998) assume that $1 \%$ of the atmospheric $\mathrm{N}$ deposited is converted into $\mathrm{N}_{2} \mathrm{O}$, and Ferm (1998) estimates that $5 \%$ of the global $\mathrm{N}_{2} \mathrm{O}$ emissions come from $\mathrm{NH}_{3}$ oxidised in the atmosphere. $\mathrm{N}_{2} \mathrm{O}$ may also be indirectly emitted outside the farm gates from leached nitrate through denitrification.

To create more environmentally sustainable dairy systems regarding the air component, it is therefore necessary to limit the emissions of GHG, together with those of ammonia. Organic farming systems may be considered as the most developed form of sustainable farming systems, as their conception is based on objectives of environmental, social and economic sustainability. The fulfilment of the aim of environmental protection has already been studied by some authors assessing the effects of organic farming on various environmental parameters, including air quality (e.g. Stockdale et al., 2001; Shepherd et al., 2003), but to our knowledge, no literature study has reviewed agricultural practices that reduce emissions of GHG and $\mathrm{NH}_{3}$ from organic dairy farming.

In this study we will analyse the mitigation options available for organic mixed crop-dairy systems, which are more common in Europe than specialised dairy or arable units (Stockdale et al., 2001). They are seen as systems having the potential to increase the efficiency of $\mathrm{N}$ cycling, thus reducing $\mathrm{N}$ losses to the environment (Ledgard, 2001). However, the combination of plant and animal production induces complex interrelations between the emissions of GHG and ammonia, which need to be studied before the implementation of mitigation options.

The mitigation options discussed in this article can also be applied beyond the scope of organic farming: they are relevant for all mixed crop-dairy systems which aim to be sustainable. Studies dealing with the mitigation of the three greenhouse gases $\mathrm{N}_{2} \mathrm{O}, \mathrm{CH}_{4}$ and $\mathrm{CO}_{2}$, as well as ammonia from dairy farming systems, are scarce (Brink et al., 2001; Wulf et al., 2002a), and consequences of mitigation options are mainly considered for individual sources or compartments of the farm and not at the whole-farm level. This article is a critical review of mitigation options accounting for direct $\mathrm{N}_{2} \mathrm{O}, \mathrm{CH}_{4}$, $\mathrm{CO}_{2}$ and $\mathrm{NH}_{3}$ emissions as well as for indirect $\mathrm{N}_{2} \mathrm{O}$ emissions through ammonia and nitrate losses and relevant for organic mixed crop-dairy systems in northern Europe.

\section{CHARACTERISTICS OF ORGANIC MIXED CROP-DAIRY SYSTEMS}

Organic systems aim to achieve a balanced relationship between soil, plants and animals (Vaarst et al., 2005). This is particularly the case in organic mixed crop-dairy systems, the crop production providing the animal feed and litter, while the animals provide the organic fertiliser through excreta (Fig. 2). Mixed crop-dairy systems will be defined here as dairy systems producing forage crops for on-farm feeding, and characterised by the integration of livestock and arable crop production, with interchange of nutrients between crop and livestock production, described as the "highly integrated system" by Watson et al. (2005).

We will consider organic farming systems as defined by European Union legislation (EU 1991, 1999, 2006). The 1804/99 European Union regulation (EU, 1999) describes in detail the allowed organic livestock management in Europe. The main differences between organic and conventional systems concern housing and grazing conditions, animal nutrition, disease prevention and veterinary treatment. Zero grazing is not permitted and the maximum value of livestock density is limited to two 
livestock units per hectare for dairy cows. For livestock housing, at least half of the total floor must be solid and not of slatted or grid construction. Dry litter must be given in the rest area. Livestock must be fed on organically produced feedstuffs and $60 \%$ of the ruminant diet must come from forage. At least $50 \%$ of the feed shall come from the farm unit itself or if not, be produced in cooperation with other organic farms. The use of synthetic amino acids and growth promoters is forbidden, as well as the use of veterinary drugs in the absence of illness.

Regarding crop production and grasslands, the main differences between organic and conventional farming concern the ban on synthetic fertilisers and pesticides (EU, 1991). Organic systems are therefore characterised by low inputs of external nutrients and chemicals into the system. Nitrogen is brought from a legume "fertility-building" phase, through clover-based leys and arable grain legumes (Stopes et al., 2002), and also through lucerne (alfalfa)-based leys. The nitrogen fixed by legumes is made available to subsequent arable crops through mineralisation. Legume-based leys are utilised for grazing and fodder.

Grasslands are key components of organic mixed cropdairy systems, by providing an important source of feed both through grazing and as hay and silage harvesting, and by contributing to building up the long-term fertility of the soil through organic matter deposition (Nicholas et al., 2004). Most organic systems have both temporary leys and permanent pastures (Nicholas et al., 2004).

Crop production is characterised by an increased diversity of cropping patterns in time and space compared with intensive conventional crop production systems (Stockdale et al., 2001). Intercrops or under-sowing are often used to maintain soil cover year-round (Stolze et al., 2000).

The animal wastes provide organic fertiliser to croplands and grasslands, thus assuring the internal recycling of nutrients. As specified in Directive 91/676/EEC (EU, 1991), the total amount of manure applied on the farm may not exceed $170 \mathrm{~kg} \mathrm{~N}$ per year/ha of agricultural area used, which corresponds to 2 dairy cows/ha/yr as defined in Annex VII of the 2092/91 European Union regulation. The regulation also indicates that the number of livestock must be closely related to the area available in order to avoid problems of over-grazing and erosion, and to allow for the spreading of livestock manure, so that any adverse effect on the environment can be avoided.

The above-mentioned differences between the organic and conventional dairy systems imply that a lot of mitigation options proposed for conventional farming are not applicable to organic farms. For instance, products of synthesis which inhibit microorganisms or modify chemical reactions producing GHG such as methanogens in enteric fermentation or nitrification in soils are not allowed in organic farming. Besides, as organic systems and particularly mixed crop-dairy systems are extensive and use low external inputs, it does not leave much room for manoeuvre for lowering system nitrogen inputs or for reducing GHG emissions compared with intensive conventional systems which, for example, import energy-costly products such as pesticides or mineral nitrogen fertilisers.

Organic mixed crop-dairy systems can show some variations due to the environment in which they operate. The differ-
Table I. Effect of slurry aeration on greenhouse gas and ammonia emissions during storage and after field application (from the results of Amon et al., 2006). Note that $\mathrm{CO}_{2}$ emissions mentioned here are not direct emissions, they correspond to a conversion of the energy requirement for the aeration process.

\begin{tabular}{cccccccc}
\hline & \multicolumn{3}{c}{ During storage } & & \multicolumn{2}{c}{ After applicaton } \\
\cline { 2 - 4 } & $\mathrm{CH}_{4}$ & $\mathrm{CO}_{2}$ & $\mathrm{~N}_{2} \mathrm{O}$ & $\mathrm{NH}_{3}$ & & $\mathrm{~N}_{2} \mathrm{O}$ & $\mathrm{NH}_{3}$ \\
\hline \multirow{2}{*}{ Slurry aeration } & $\searrow$ & $\nearrow$ & $\nearrow$ & $\nearrow$ & & $\nearrow$ & $\nearrow$ \\
\hline
\end{tabular}

ences in livestock production will mainly consist of the land use (\% of grasslands), the grassland management, the level of concentrates in the diet (between 0 and $40 \%$ ), the dairy herd policy (size of the dairy herd, \% of annual replacement, stocking density) and manure management. For instance, in the organic sector, Stolze et al. (2000) reported absolute livestock density of 1.6-1.8 livestock units (LU) per ha in the UK, but only 1.0 LU per ha on comparable organic farms in Germany. Some indications about the differences existing between organic dairy farming systems in Northern European countries can be found in Pflimlin and Kempf (2002), Weller (2002), Häring (2003), and Mosimann and Suter (2003). Crop production will mainly differ in crop rotation, soil tillage and fertilisation.

\section{REVIEW OF MITIGATION OPTIONS AVAILABLE FOR ORGANIC MIXED CROP-DAIRY SYSTEMS}

In general, mitigation measures may consist either of reducing or preventing the emissions of GHG and ammonia at source, or of favouring the storage of carbon in plants or soils. The mitigation measures for dairy production systems can be either technical (e.g. manure application techniques), management-based (e.g. changes in grazing/housing patterns) or system-orientated (e.g. shift from conventional to organic farming) (Weiske et al., 2006).

Mitigation options show strong interrelations both between gases (more than one gas is affected either beneficially or adversely) and between farm compartments (the control of the emission of one compound may increase its emission at another stage of management). For instance, Amon et al. (2006) showed that intermittently aerating dairy cattle slurry had contrasting results on GHG and $\mathrm{NH}_{3}$ emissions, and that slurry aeration affected the emissions not only during the storage period but also after slurry application (Tab. I). It is therefore important to assess mitigation options for their impact upon the carbon and nitrogen cycles at the whole-farm level, by taking into account not only GHG and $\mathrm{NH}_{3}$, but also $\mathrm{NO}_{3}^{-}$leaching and $\mathrm{C}$ storage.

One must also consider that all the GHG do not affect global warming with the same intensity. Over the 100-year timescale, the Global Warming Potential from methane and nitrous oxide is estimated at 25 and 298 , respectively, times that of $\mathrm{CO}_{2}$ (Forster et al., 2007). A small increase in $\mathrm{N}_{2} \mathrm{O}$ emissions may thus counterbalance a large decrease in $\mathrm{CH}_{4}$ 
emissions. Therefore, to be effective, mitigation options have to induce an overall reduction of GHG emissions in terms of $\mathrm{CO}_{2}$ equivalents in addition to a reduction in $\mathrm{NH}_{3}$ losses.

A large number of studies on reducing emissions from dairy systems have already been carried out, either for greenhouse gases (e.g. Velthof et al., 1998; Amon et al., 2001a; Clemens and Ahlgrimm, 2001; Monteny et al., 2006; Schils et al., 2006; Weiske et al., 2006) or for ammonia (e.g. Bussink and Oenema, 1998; Malgeryd, 1998; Webb et al., 2005). We will focus here on the mitigation strategies suitable for organic mixed crop-dairy systems in northern Europe, by considering their different compartments (Fig. 2), grouped together into three subsystems: i/ animal production, which includes livestock and manure management, ii/ crop production dealing with crop rotation, fertilisation and soil tillage, and iii/ grasslands, grazed (pastures) or cut (meadows). Due to the lack of bibliographic data, we will not consider the emissions generated by the feed and bedding stores themselves.

\subsection{Animal production}

\subsubsection{Livestock management}

\subsubsection{Feeding strategies}

Enteric fermentation in the cattle rumen is the major source of $\mathrm{CH}_{4}$ emissions in dairy systems, but also the most difficult to reduce. The techniques currently being developed to reduce it by direct rumen manipulation (see e.g. Boadi et al., 2004; Martin et al., 2006) will not be discussed here as they are beyond the scope of organic farming. We will focus here on nutritional strategies consisting either of adding lipids to the diet, changing its fibre content or selective grazing. Linseed fatty acids supplemented at 6\% were shown (Martin et al., 2008) to reduce dairy cow $\mathrm{CH}_{4}$ emissions from 12 to $64 \%$ depending on the physical form of the lipid (crude linseed, extruded linseed or linseed oil). Furthermore, crude linseed increased milk yield, but not linseed oils. Linseed lipids are allowed as feed materials in organic dairy farming in the form of seeds or oil if the extraction process is physical (EU, 2006). Their promising results on $\mathrm{CH}_{4}$ emissions need, however, to be confirmed by studies on more animals, taking into account the interaction with the nature of the basal diet and considering the effects of linseed on milk production.

Changing diet composition through the replacement of some of the grazing and roughage by concentrates (which have to represent less than $40 \%$ of the diet in organic dairy farming) increases animal productivity and may decrease the numbers of cows required to fill the annual milk quota (Lovett et al., 2006) and thus the $\mathrm{CH}_{4}$ emissions per unit of milk. However, it goes against the general aim of organic dairy farming to produce milk with a minimum of external inputs. Increasing the proportion of concentrate in the diet also has other direct and indirect effects on GHG and ammonia emissions. For instance, although supplementation of diets with concentrates often diminishes enteric methane emissions from cows, it may simultaneously enhance slurry methanogenesis because this is associated with extra amounts of undigested fibre which may be a substrate for slurry microbes (Hindrichsen et al., 2006). The fibre and the protein content of cattle diets were also shown to significantly influence the ammonia emission rates of manure (Kulling et al., 2003), as well as the plant availability of cattle slurry $\mathrm{N}$ and the amount of residual slurry $\mathrm{N}$ remaining in the soil after the first growing season (Sorensen et al., 2003). Moreover, replacing roughage by concentrates also contradicts the European environmental policy to promote extensive use of maintained grasslands, which store significant amounts of carbon in soil (Freibauer et al., 2004). Besides, the production and transport of concentrates generate GHG.

Because of its high starch content, the increased use of maize silage relative to dry matter intake was also suggested to reduce enteric $\mathrm{CH}_{4}$ (Mills et al., 2001) and to improve animal performance. However, there is a need for animal studies that directly compare maize and other cereal silage with grass silage to quantify the reduction in $\mathrm{CH}_{4}$ that might be achieved (Beauchemin et al., 2008). Furthermore, these inputs must be evaluated in terms of the net contribution to total GHG to evaluate if the substitution of maize or cereal silage for grass silage will result in a net reduction in GHG emissions on the farm scale.

Forage species also affect $\mathrm{CH}_{4}$ production in ruminants (McAllister et al., 1996). Measurements of $\mathrm{CH}_{4}$ production from grazing beef cows indicated a $25 \%$ reduction in $\mathrm{CH}_{4}$ losses with alfalfa-grass pastures ( $7.1 \%$ of gross energy intake) compared with grass-only pastures (9.5\% of gross energy intake) (McCaughey et al., 1999). The introduction of legumes into grazed grasslands would therefore limit $\mathrm{CH}_{4}$ emissions. Legume species also seem to affect the $\mathrm{CH}_{4}$ production from ruminants. For instance, condensed tannin-containing legumes (such as sulla) were shown to reduce the $\mathrm{CH}_{4}$ emissions of dairy cows and other ruminants (Woodward et al., 2002; Tavendale et al., 2005).

The control of the protein intake of animals to meet their requirements more precisely is proposed to reduce gaseous emissions of nitrogen in grazed pastures, since excess $\mathrm{N}$ in the diet of cattle is to a large extent excreted in the urine, which in turn can influence ammonia and $\mathrm{N}_{2} \mathrm{O}$ emissions (Oenema et al., 2005; Watson et al., 2005; Kebreab et al., 2006). Controlling the $\mathrm{N}$ content of the diet is, however, not easy in organic dairy farming systems, since herbage plays an important role in the diet and because the proportion of legumes can vary greatly between swards through the seasons and between years. The $\mathrm{N}$ content of legumes is generally much higher than that required for optimum animal nutrition (Ledgard, 2001). However, as discussed above, $\mathrm{CH}_{4}$ production (expressed relative to gross energy intake) from the rumen fermentation of legume forages is generally lower than the production from grass forage.

\subsubsection{Genetic selection}

Genetic selection of cows based on an improvement of their ability to produce less methane or of their feed efficiency is still under validation (Boadi et al., 2004; Martin et al., 2006). The genetic selection of cows producing higher yield and thus 
Table II. Effects on greenhouse gas and ammonia emissions of mitigation options reported for livestock management.

\begin{tabular}{|c|c|c|c|c|c|}
\hline \multicolumn{2}{|c|}{ Mitigation options for livestock management } & $\mathrm{CH}_{4}$ & $\mathrm{~N}_{2} \mathrm{O}$ & $\mathrm{CO}_{2}$ & $\mathrm{NH}_{3}$ \\
\hline \multirow{5}{*}{ Feeding strategy } & Adding linseed lipids to the diet & \multirow{2}{*}{$\begin{array}{c}\mathbf{y} \text { ? } \\
\boldsymbol{y} \text { from animals } \\
\boldsymbol{\lambda} \text { from slurry? }\end{array}$} & - & - & - \\
\hline & $\begin{array}{l}\text { Increasing the proportion of } \\
\text { concentrate in the diet }\end{array}$ & & $\begin{array}{c}\boldsymbol{\lambda} \text { or } \boldsymbol{y} ? \\
\left(\text { from slurry }{ }^{\mathrm{a}}\right)\end{array}$ & $\begin{array}{l}\boldsymbol{\lambda} \text { (fossil energy } \\
+ \text { soil) }\end{array}$ & $\begin{array}{c}\boldsymbol{\lambda} \text { or } \boldsymbol{y} ? \\
\left(\text { from slurry }^{\mathrm{a}}\right)\end{array}$ \\
\hline & $\begin{array}{l}\text { Increasing the proportion of } \\
\text { maize silage in the diet }\end{array}$ & $\mathbf{y}$ from animals & - & - & - \\
\hline & $\begin{array}{l}\text { Introducing legumes into grazed } \\
\text { grasslands }\end{array}$ & ע & $\pi ?$ & y? & $\pi ?$ \\
\hline & Limiting excess $\mathrm{N}$ in the diet & $\lambda ?$ & $\mathbf{y}$ & - & ע \\
\hline \multirow{3}{*}{ Genetic selection } & Selecting cows with low enteric & y? & - & - & - \\
\hline & $\mathrm{CH}_{4}$ production & & & & \\
\hline & Selecting high-yielding cows & ע or $\pi$ ? & - & - & $y^{b}$ or $\pi$ ? \\
\hline \multirow[b]{2}{*}{ Herd characteristics } & Reducing the replacement rate & $y ?$ & - & - & - \\
\hline & $\begin{array}{l}\text { Reducing the number of } \\
\text { milking cows }\end{array}$ & ע & $y$ & $y$ & $y$ \\
\hline
\end{tabular}

${ }^{\text {a }}$ Depending on the $\mathrm{N}$ content of the concentrate compared to the roughage;

${ }^{\mathrm{b}}$ Results from Lovett et al. (2006).

Caption:

$\mathbf{y}:$ the mitigation option decreases the emissions

$\boldsymbol{\lambda}$ : the mitigation option increases the emissions

" $\boldsymbol{y}$ or $\boldsymbol{\lambda}$ ": both tendencies have been shown

- : no information was given on this compound

0: studies have shown that this option had no significant effect on this compound

?: the result needs to be confirmed by more studies.

less $\mathrm{CH}_{4}$ per unit of milk often leads to a decrease in animal fertility and health (especially with Holstein cows) and to an increase in the overall replacement rate (Lovett et al., 2006). This may paradoxically involve an increase in herd size, with heifers emitting GHG and $\mathrm{NH}_{3}$, which will increase the emissions from the whole farm.

\subsubsection{Herd characteristics}

Options that increase lifetime efficiency or reduce the replacement rate are likely to reduce GHG emissions at the farm level, as shown in a modelling study from Weiske et al. (2006). This means that the decision to replace cows should not be based solely on economic considerations or fertility, but also on their capacity to produce milk for a long time. This could, for instance, be achieved by dairy cows resistant to illness and better adapted to the environment of their farm rather than high-yielding animals. Finally, reducing the milk production through the reduction of the number of milking cows certainly decreases the GHG and $\mathrm{NH}_{3}$ emissions at the farm level, but this would mean a profound change in the farm economy.

In conclusion, Table II summarises the effects on GHG and $\mathrm{NH}_{3}$ emissions of the different mitigation options discussed for livestock management. In the current state of knowledge, two main mitigation strategies can be drawn from the abovementioned options, based on either: $1 /$ a herd with a limited number of high-yielding dairy cows fed with an energy-rich ration but probably needing a high replacement rate; $2 /$ a herd with animals bred for hardiness, less productive but more robust and long-lived.
As methane production from enteric fermentation is rather hard to reduce, mitigation strategies from organic dairy farming have focused on the reduction of $\mathrm{CH}_{4}$ emissions from manure management.

\subsubsection{Manure management}

All parts of the manure handling chain, i.e. housing, storage and application, need to be considered, since intervening in one part affects losses in another. As mentioned in the introduction, the manure handling chain may be a source of GHG as well as ammonia. The organic European Union standards require that straw-based housing systems have to be used in organic livestock production. Manure management in organic dairy farming is thus based on the farmyard manure system, which may vary according to the amount of straw used. This amount will particularly determine whether all urine and faeces are retained by straw and stored as farmyard manure or if part of the urine is stored as liquid manure.

\subsubsection{Housing}

Ammonia losses from buildings are usually the second largest sources of $\mathrm{NH}_{3}$ after slurry application (Bussink and Oenema, 1998). $\mathrm{NH}_{3}$ emissions from the buildings may be reduced by increasing the amounts of straw used for bedding, with the advantage of no subsequent increase in $\mathrm{NH}_{3}$ losses during the storage or spreading of the manure, as all the ammoniacal nitrogen is immobilised in the straw (Webb et al., 2005). 
Deep litter may result in significant emissions of $\mathrm{N}_{2} \mathrm{O}$ and $\mathrm{CH}_{4}$, depending on the rate of litter addition and mixing (Monteny et al., 2001; Oenema et al., 2005). Options to reduce $\mathrm{CH}_{4}$ emissions consist here of avoiding anaerobic conditions in the bedding.

\subsubsection{Manure storage}

Manure stores are the second largest source of methane emissions (after enteric fermentation) in European dairy farming (Sneath et al., 2006). $\mathrm{CH}_{4}$ emissions arise mainly from slurry stores, whereas farmyard manure stores are a significant source of $\mathrm{N}_{2} \mathrm{O}$ (Chadwick et al., 1999). Slurry and farmyard manure stored outside are also significant sources of $\mathrm{NH}_{3}$ but they show great variations according to the temperature, the surface area, the duration of storage, and the occurrence of mechanical aeration (Bussink and Oenema, 1998).

The choice of a mitigation option at this stage of the manure handling chain will mainly depend on the nature of the effluent (liquid or solid manure).

\subsection{Mitigation options during the storage of liquid manure}

\section{Overcoming the effect of storage temperature}

In northern European conditions, grazing is generally not possible during late autumn and in winter and cows are kept in buildings during this period. Slurry is therefore collected from cowsheds under cold conditions. Several studies have shown that $\mathrm{CH}_{4}$ and $\mathrm{NH}_{3}$ emission rates for slurry increased significantly with storage temperatures (Husted, 1994; Bussink and Oenema, 1998; Sommer et al., 2000; Clemens et al., 2006). For instance, Husted (1994) reported an increase of $61 \%$ in the overall methane emissions if the slurry was applied in September instead of June. Emptying the slurry store before the increase in air temperature (i.e. before late spring) would therefore limit the emissions of $\mathrm{NH}_{3}$ and $\mathrm{CH}_{4}$ that occur during the storage of liquid manure, as well as $\mathrm{NH}_{3}$ emissions resulting from field application which are also increased at higher air temperature (Sommer and Hutchings, 2001). However, other factors than air temperature must be considered, such as the load-bearing capacity of soils and the risk of nitrate leaching, which often limit the application of the stored slurry in autumn and winter. To overcome the effect of temperature when liquid manure is stored for a long time, some authors proposed cooling the manure tank (Clemens and Ahlgrimm, 2001; Monteny et al., 2001), but this requires fossil energy.

\section{Favouring the formation of a surface crust}

A natural crust generally forms at the slurry surface during storage as a result of evaporation, which promotes drying and binding of the particles if the slurry is not disturbed by mechanical mixing. The formation of this natural crust has been shown to greatly reduce $\mathrm{NH}_{3}$ losses (by $50 \%$ in the study of Misselbrook et al. (2005) and by $80 \%$ in the study of Sommer et al. (1993)) and $\mathrm{CH}_{4}$ emissions (by $38 \%$ in the study of Sommer et al. (2000) and by a factor of 12 in the study of Husted (1994)). Petersen et al. (2005) gave evidence for methanotrophic activity, i.e. methane oxidation, in surface crust materials. Measures to ensure crust formation are thus a cost-effective way of mitigating $\mathrm{NH}_{3}$ and $\mathrm{CH}_{4}$ emissions during the storage of slurry. They may, however, favour $\mathrm{N}_{2} \mathrm{O}$ emissions, which were shown to increase under warm conditions for slurry covered with a natural crust (Sommer et al., 2000).

The concentration and nature of the solids present in the slurry, which are influenced by the cattle diet and bedding material used, are important in determining crust formation, as well as environmental factors such as temperature, wind speed and rainfall (Misselbrook et al., 2005). These authors found that slurry dry matter content was the most important factor influencing crust formation, with no crust formation on slurries with a dry matter content below $1 \%$. They also observed large differences in crust formation on slurries from grass silagefed cattle bedded on long straw compared with corn silage-fed cattle bedded on chopped straw, but with no significant differences in $\mathrm{NH}_{3}$ emission rates. Disturbance of the crust during the regular transfer of slurry from buildings could be minimised by inserting the nozzle of the liquid manure spreader below the surface crust, and homogenisation before emptying can be achieved by mixing with or without destroying the surface crust (Petersen et al., 2005).

\section{Covering slurry tanks}

A wooden cover on slurry tanks has also been reported as an effective technique to reduce $\mathrm{CH}_{4}$ and $\mathrm{NH}_{3}$ emissions (Amon et al., 2006; Clemens et al., 2006), and $\mathrm{N}_{2} \mathrm{O}$ emissions under cold conditions. Covering the tank may increase $\mathrm{N}_{2} \mathrm{O}$ emissions in warm conditions, but as $\mathrm{CH}_{4}$ emissions during slurry storage contribute more to total GHG emissions than $\mathrm{N}_{2} \mathrm{O}$ emissions, a lid has benefits as regards climate change. It may also shelter the natural surface crust from rain and help to keep it dry during winter. On the other hand, excluding rainwater from the slurry store may decrease the slurry water content, thus making its field application more difficult. Addition of a wooden cover reduces $\mathrm{CH}_{4}$ and $\mathrm{NH}_{3}$ emissions from slurry more than a natural surface crust alone. Covers made with other materials, such a chopped straw or wood, or expanded clay, have been shown to reduce $\mathrm{NH}_{3}$ losses but not overall GHG (and particularly $\mathrm{CH}_{4}$ ) emissions (Amon et al., 2006; Clemens et al., 2006; Guarino et al., 2006).

\section{Performing anaerobic digestion}

Anaerobic digestion of manure has been proposed by many authors (e.g. Clemens et al., 2006; Monteny et al., 2006; Weiske et al., 2006) as a measure to abate $\mathrm{CH}_{4}$ emissions 
from manure storage. Anaerobic digestion is a natural process whereby bacteria existing in oxygen-free environments decompose organic matter, resulting in a biogas (a mixture of $\mathrm{CH}_{4}, \mathrm{CO}_{2}$ and some trace gases) and a sludge that is stable and nearly odourless (Kebreab et al., 2006). Methane produced by digesters can be captured and burned as fuel. Anaerobic digestion in a covered gas-tight plant thus offers the benefits of reducing trace gas emissions and substituting fossil fuels by renewable energy (biogas).

Few studies have been done on the GHG and $\mathrm{NH}_{3}$ emissions of slurry after its anaerobic digestion. During winter storage in pilot-scale slurry tanks, Clemens et al. (2006) reported significantly lower $\mathrm{CH}_{4}$ emissions from digested dairy cattle slurry than from the same untreated slurry (emissions of $\mathrm{N}_{2} \mathrm{O}$ and $\mathrm{NH}_{3}$ were similar for the two slurries). These authors emphasise the importance of the digestion's duration (hydraulic retention time), which must be sufficiently long for a complete degradation of fermentable organic matter, so as to exploit the potential for gas production without increasing $\mathrm{CH}_{4}$ emissions during subsequent storage.

However, even with a sufficiently long hydraulic retention time, $\mathrm{CH}_{4}$ is still produced after anaerobic digestion. Clemens et al. (2006) therefore recommend including all potentially gas-producing compounds within biogas plants for complete collection of $\mathrm{CH}_{4}$ and optimum environmental and economic benefit. It is also important to prevent uncontrolled losses of methane from biogas plants (which occur, e.g., by mean of small leakages) which can considerably alter the environmental balance of a biogas production system (Borjesson and Berglund, 2006).

After field application, Clemens et al. (2006) found no significant differences in GHG emissions between untreated and digested cattle slurry, whereas Petersen (1999) reported lower $\mathrm{N}_{2} \mathrm{O}$ emissions from digested slurry compared with untreated slurry. $\mathrm{NH}_{3}$ losses after field application of digested slurry have been reported to be similar to (Rubaek et al., 1996; Clemens et al., 2006; Wulf et al., 2002b), lower than (Rubaek et al., 1996) or higher than (Amon et al., 2006) those from raw slurry. These contrasting results are probably attributable to the effects of anaerobic digestion on both chemical and physical properties of the slurry. Anaerobic digestion reduces manure carbon and dry matter content by about $50 \%$ but generally results in an increase in $\mathrm{NH}_{4}^{+}$content and $\mathrm{pH}$ (Wulf et al., 2002b; Amon et al., 2006). The reduced viscosity of digested slurry improves its infiltration, thus limiting the $\mathrm{NH}_{3}$ volatilisation, whereas its higher $\mathrm{NH}_{4}^{+}$content and $\mathrm{pH}$ promote the $\mathrm{NH}_{3}$ losses. $\mathrm{NH}_{3}$ emissions from digested slurry can therefore be reduced if the increased potential loss due to chemical factors is compensated for by its faster infiltration (Wulf et al., 2002b). Techniques to reduce $\mathrm{NH}_{3}$ emissions from field application will be discussed later.

In France, Ademe et al. (2006) estimated 200-250 k euros as the cost of a biogas installation producing $30 \mathrm{~kW}$ of electricity. In organic dairy farming, two other limitations must be taken into account: $1 /$ slurry is only collected at one time of the year (i.e. during housing) and 2/ co-digestion with other waste products to increase gas production is not feasible, particularly because they should also come from organic farming unless the digested product is not used for an organic farm. The economical feasibility of on-farm power/heat generation with biogas will depend to a great extent on the energy price and on subsidies.

\section{Performing a mechanical separation}

Mechanical separation is another technique used to treat slurry, resulting in a liquid fraction with low dry matter content reduced by $40-45 \%$, and a solid fraction that can be stored in heaps. Separation is performed with a screw sieve separator and uses little energy. The separated slurry has a lower viscosity and flows more easily through band-spreading hoses. The study of Amon et al. (2006) indicates that slurry separation reduces $\mathrm{CH}_{4}$ emissions, but is likely to result in an increase in $\mathrm{N}_{2} \mathrm{O}$ and $\mathrm{NH}_{3}$ emissions during composting of the solid fraction.

\section{Lowering the pH of slurry}

Lowering the $\mathrm{pH}$ of slurry with additives such as lactic acid has also been proposed to avoid the production of methane, this acid being authorised in organic farming not intentionally for that purpose but for the cleaning and the disinfection of livestock buildings and installations. Lowering the $\mathrm{pH}$ of the slurry with lactic acid can indeed reduce both $\mathrm{CH}_{4}$ and $\mathrm{N}_{2} \mathrm{O}$ emissions, but Berg et al. (2006) showed that this reduction is effective only if the $\mathrm{pH}$ is below 6.0 , and that a lower $\mathrm{pH}$ would be necessary to reduce ammonia emissions. This technique seems therefore not to be practically possible.

\section{Aerating the slurry}

As oxygen is a strong inhibitor of methane production and an easily available product, aeration seems an attractive method to limit $\mathrm{CH}_{4}$ emissions. Aeration was indeed shown to reduce $\mathrm{CH}_{4}$ emissions of slurry during its storage (Martinez et al., 2003; Amon et al., 2006), but $\mathrm{N}_{2} \mathrm{O}$ and $\mathrm{NH}_{3}$ emissions may be greatly increased when the slurry is aerobically treated (Béline et al., 1999; Amon et al., 2006). $\mathrm{N}_{2} \mathrm{O}$ may also be emitted by the aerated slurry during its subsequent storage (Béline et al., 1999). Besides, slurry aeration results in energy consumption. Nevertheless, laboratory studies showed that the aeration strategy (intermittent or continuous, length of the anoxic period) would play an important role in the emissions of $\mathrm{N}_{2} \mathrm{O}$ (Béline and Martinez, 2002). However, these results need to be confirmed by experiments on farm-scale units.

\section{Comparison of treatments}

Comparing the effect of different treatments of dairy cattle slurry (wooden or straw cover, mechanical separation, anaerobic digestion, aeration), Amon et al. (2006) found that anaerobic digestion reduced the overall GHG emissions from storage 
Emissions (\%w versus untreated slurry)

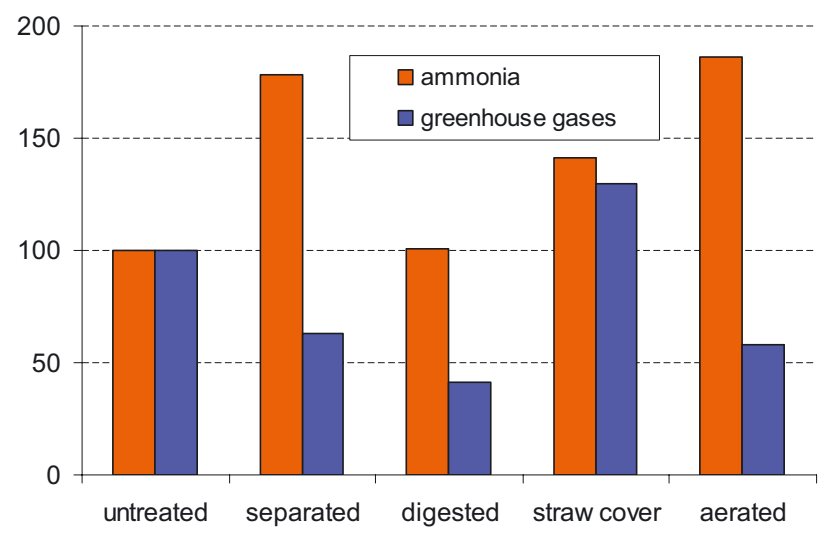

Figure 3. Relative ammonia and greenhouse gas emissions from storage and land spreading for different treatments of dairy cattle slurry compared with untreated slurry with a wooden cover (from Amon et al., 2006).

and land spreading the most, and had hardly any influence on $\mathrm{NH}_{3}$ emissions from these processes (Fig. 3). This study has the asset of having been conducted in pilot-scale tanks whose conditions are nearer to field conditions than studies with laboratory reactors.

\subsection{Mitigation options during the storage of solid manure}

The use of straw for bedding in organic dairy housing systems produces solid manure, which can be either composted or stored outdoors stockpiled.

\section{Composting solid manure}

Organic systems encourage the composting of solid manure, i.e. aerobic decomposition at temperatures of around $60{ }^{\circ} \mathrm{C}$, which offers the advantages of producing a more stable, uniform product, free of weeds and toxins and easier to spread (Mustin, 1987; Peigne and Girardin, 2004). However, the heat generated and the regular aeration by turning of the heap during the early stages of composting favour ammonia losses which are generally greater than for stockpiled farmyard manure (Amon et al., 2001b; Gibbs et al., 2002; Peigne and Girardin, 2004). Although $\mathrm{NH}_{3}$ losses are large during the composting phase, they are low after subsequent soil application, because the remaining $\mathrm{N}$ is mainly in organically bound forms and thus concentrations of inorganic $\mathrm{N}$ are very low (Sommer and Hutchings, 2001; Amon et al., 2001b; McNeill et al., 2005).

Mechanical turning of composted manure generally results in lower $\mathrm{N}_{2} \mathrm{O}$ and $\mathrm{CH}_{4}$ emissions than for anaerobically stacked farmyard manure (Amon et al., 2001b; Peigne and Girardin, 2004). Considering the whole management system (housing, storage and spreading), Amon et al. (2001b) re- ported $\mathrm{GHG}\left(\mathrm{CH}_{4}+\mathrm{N}_{2} \mathrm{O}\right)$ emissions $25 \%$ lower from a composting system than from an anaerobic stacking system. Significant amounts of $\mathrm{CO}_{2}$ may, however, be emitted during the composting process, but it is not a net source of $\mathrm{CO}_{2}$ along the recycling chain of agricultural wastes, since well-composted material contains less easily decomposable carbon compounds than non-decomposed material (Peigne and Girardin, 2004). Composted manures being less degradable than fresh manures, their application permits greater carbon storage in the soil (Kirchmann and Bernal, 1997).

GHG and ammonia emissions during composting are greatly influenced by its management (turning method and frequency, duration of the composting operations) and by the physical and chemical characteristics of the raw material $(\mathrm{C} / \mathrm{N}$ ratio) (Peigne and Girardin, 2004). A high porosity of the initial material provides sufficient aeration, which is essential for a good composting process and for limiting $\mathrm{N}_{2} \mathrm{O}$ and $\mathrm{CH}_{4}$ emissions. An increase in the $\mathrm{C} / \mathrm{N}$ ratio significantly reduces $\mathrm{N}$ losses during storage and composting of livestock solid manure (Sommer, 2001). If the density of the farmyard manure is high (low porosity) or the $\mathrm{C} / \mathrm{N}$ ratio is low $(<20)$, straw may be added to the farmyard manure to improve its composting. Furthermore, the number and frequency of turnings can be reduced if the raw material has good characteristics (Peigne and Girardin, 2004), thus limiting $\mathrm{NH}_{3}$ losses.

Considering indirect $\mathrm{N}_{2} \mathrm{O}$ emissions, a concrete platform with water recovery is the best system to prevent nitrate losses by leaching or runoff from the compost heap to surface or groundwater (Peigne and Girardin, 2004). Covering the pile with a waterproof but air-permeable cover is another way to avoid contamination by runoff (Peigne and Girardin, 2004). However, nitrate leaching losses from compost with a high $\mathrm{C} / \mathrm{N}$ ratio are generally low (Sommer, 2001).

\section{Compacting and covering manure heaps}

Compacting and covering manure heaps has the potential to reduce emissions of both $\mathrm{NH}_{3}$ and $\mathrm{N}_{2} \mathrm{O}$ when the manure contains relatively high ammonium- $\mathrm{N}$ contents (Chadwick, 2005). Compaction may, however, increase $\mathrm{CH}_{4}$ emissions (Chadwick, 2005; Oenema et al., 2005). Covering manure heaps may also not always be effective, because the mineralisation rate increases with temperature, and so the effect of increased mineralisation may exceed the effect of reduced exchange rates of $\mathrm{NH}_{3}$ from the manure with the atmosphere (Bussink and Oenema, 1998). Addition of straw to solid manure is another way of reducing $\mathrm{NH}_{3}$ emissions by improving the $\mathrm{C} / \mathrm{N}$ ratio (Clemens and Ahlgrimm, 2001), and it was also shown to reduce $\mathrm{CH}_{4}$ and $\mathrm{N}_{2} \mathrm{O}$ emissions (Yamulki, 2006).

Reductions in $\mathrm{NH}_{3}$ emissions at the manure storage stage will result in increased manure total ammoniacal nitrogen content and therefore in potentially larger losses following land spreading (Misselbrook et al., 2005). It is therefore important that suitable application or incorporation methods are used to minimise losses. 


\subsubsection{Application techniques}

Slurry application is the major source of ammonia emissions in dairy farming systems (Bussink and Oenema, 1998) and it is to a lesser extent a direct source of $\mathrm{N}_{2} \mathrm{O}$ (Oenema et al.; 2005). Significant $\mathrm{NH}_{3}$ and $\mathrm{N}_{2} \mathrm{O}$ emissions also occur following the application of farmyard manure (Webb et al., 2004). In addition to being a direct source of $\mathrm{N}_{2} \mathrm{O}$, manure spreading may be an indirect source of this gas through ammonia losses and nitrate leaching. In general, the reduction of $\mathrm{NH}_{3}$ emissions is more effective at the spreading phase than from buildings (Webb et al., 2005).

\subsection{Spreading manure during the coolest part of the day}

A "simple" mitigation method is to limit the application of manure to when conditions do not favour $\mathrm{NH}_{3}$ volatilisation, e.g. during the coolest part of the day. Sommer and Olesen (2000) have calculated that avoiding applications during times of the day with a high potential for $\mathrm{NH}_{3}$ losses could reduce the total emission of $\mathrm{NH}_{3}$ from applied slurry by half. However, the efficiency of this technique depends on the farmer's flexibility in the choice of application date and time (Sommer and Hutchings, 2001).

\subsection{Incorporating manure}

Several techniques of manure spreading on land have been shown to decrease $\mathrm{NH}_{3}$ losses (Sommer and Hutchings, 2001). Among them, rapid incorporation of manures into arable land by ploughing is the most cost-effective (Webb et al., 2005). Incorporation should be as soon after application as possible, especially after slurry application, as loss rates are high in the first hours after application (Sommer and Hutchings, 2001). For slurry, the use of disk or tine cultivators may be as effective as ploughing (Webb et al., 2005). Incorporating manure was found to increase (Ferm et al., 1999) or decrease $\mathrm{N}_{2} \mathrm{O}$ emissions by soils (Webb et al., 2004). It is therefore not possible to generalise the effects of manure incorporation into the soil on $\mathrm{N}_{2} \mathrm{O}$ emission, most probably because the denitrification process in soils depends on many factors (see e.g. Oenema et al., 2005; Mathieu et al., 2006).

\subsection{Spreading the slurry in bands}

The application of slurry in narrow bands (i.e. band spreading), rather than over the entire soil or crop surface, by trailing hose or trailing shoe was also shown to be an effective technique to reduce $\mathrm{NH}_{3}$ losses after liquid manure spreading (Webb et al., 2005). The effectiveness of band spreading increases if the slurry is placed below the canopy of a welldeveloped crop (Webb et al., 2005). Trail hoses or trail shoes have the advantage of limiting $\mathrm{N}_{2} \mathrm{O}$ emissions in comparison with slurry injection, which reduces $\mathrm{NH}_{3}$ emissions reliably but may greatly enhance $\mathrm{N}_{2} \mathrm{O}$ emissions (Flessa and Beese, 2000). Injection of slurry also causes higher fuel consumption (Wulf et al., 2002a). Trail hoses are, in general, more effective on arable land than on grassland and when used with dilute than with more viscous slurries, whereas trail shoes are designed more for grasslands (Webb et al., 2005).

Investigating the effect of different application techniques on greenhouse gas and ammonia emissions from co-fermented slurry, Wulf et al. (2002a) found that the most effective methods to limit both GHG and ammonia emissions were trail hose application with immediate shallow incorporation for arable land, and trail shoe application for grassland.

One must also consider the indirect effects on GHG emissions of an improved application of manure in the field (Weiske et al., 2006). For instance, as $\mathrm{NH}_{3}$ losses from the manure are reduced, there are less indirect emissions of $\mathrm{N}_{2} \mathrm{O}$ due to deposition of $\mathrm{NH}_{3}$ outside the field. But as more nitrogen is effectively applied to soil, nitrate leaching is likely to increase and hence the derived $\mathrm{N}_{2} \mathrm{O}$ emissions. This can, however, be counterbalanced by increased crop yields resulting from the increased amount of nitrogen available for the crops.

The effects of timing applications to match crop demand are discussed later in the "crop production" section.

\subsubsection{Solid versus liquid manure}

Depending on the amount of straw used for bedding, the manure handling chain will manage straw-based manure only, both solid (straw-based) and liquid (slurry-based) manures or even liquid manure only. We report here the results of studies or reviews comparing the emissions of GHG or $\mathrm{NH}_{3}$ of strawmanure-based systems versus slurry-based ones. From different experimental studies, Monteny et al. (2006) concluded that animal housing and manure stores of straw-based systems (deep litter) result in greater $\mathrm{N}_{2} \mathrm{O}$ emissions than the more anaerobic slurry-based systems. On the other hand, several studies reported substantially lower $\mathrm{N}_{2} \mathrm{O}$ emissions following the application of solid manure compared with the application of liquid manure (Gregorich et al., 2005).

Concerning $\mathrm{CH}_{4}$, Stolze et al. (2000) estimated that lower potential $\mathrm{CH}_{4}$ emissions are likely for straw-based manure because stable manure has a significantly lower metabolic factor for methane than liquid manure. Conversely, Monteny et al. (2001) hypothesised that deep litter systems may emit larger quantities of $\mathrm{CH}_{4}$ than slurry-based systems, due to the increased temperature in the deep litter bed and (partially) anoxic conditions resulting from compaction by the animals. On the other hand, Hansen et al. (2002) estimated that $\mathrm{CH}_{4}$ emissions from deep litter were similar to those of slurrybased housing systems. The application of solid manure generally results in higher $\mathrm{C}$ storage than slurry (Foereid and Hogh-Jensen, 2004; Ceotto et al., 2006). Concerning $\mathrm{NH}_{3}$, increased use of straw for bedding is likely to reduce $\mathrm{NH}_{3}$ emissions from housing (Bussink and Oenema, 1998; Stockdale et al., 2001).

These sometimes conflicting results show the difficulty in drawing conclusions about the magnitude of GHG and $\mathrm{NH}_{3}$ 
Table III. Effects on greenhouse gas and ammonia emissions of mitigation options reported for manure management.

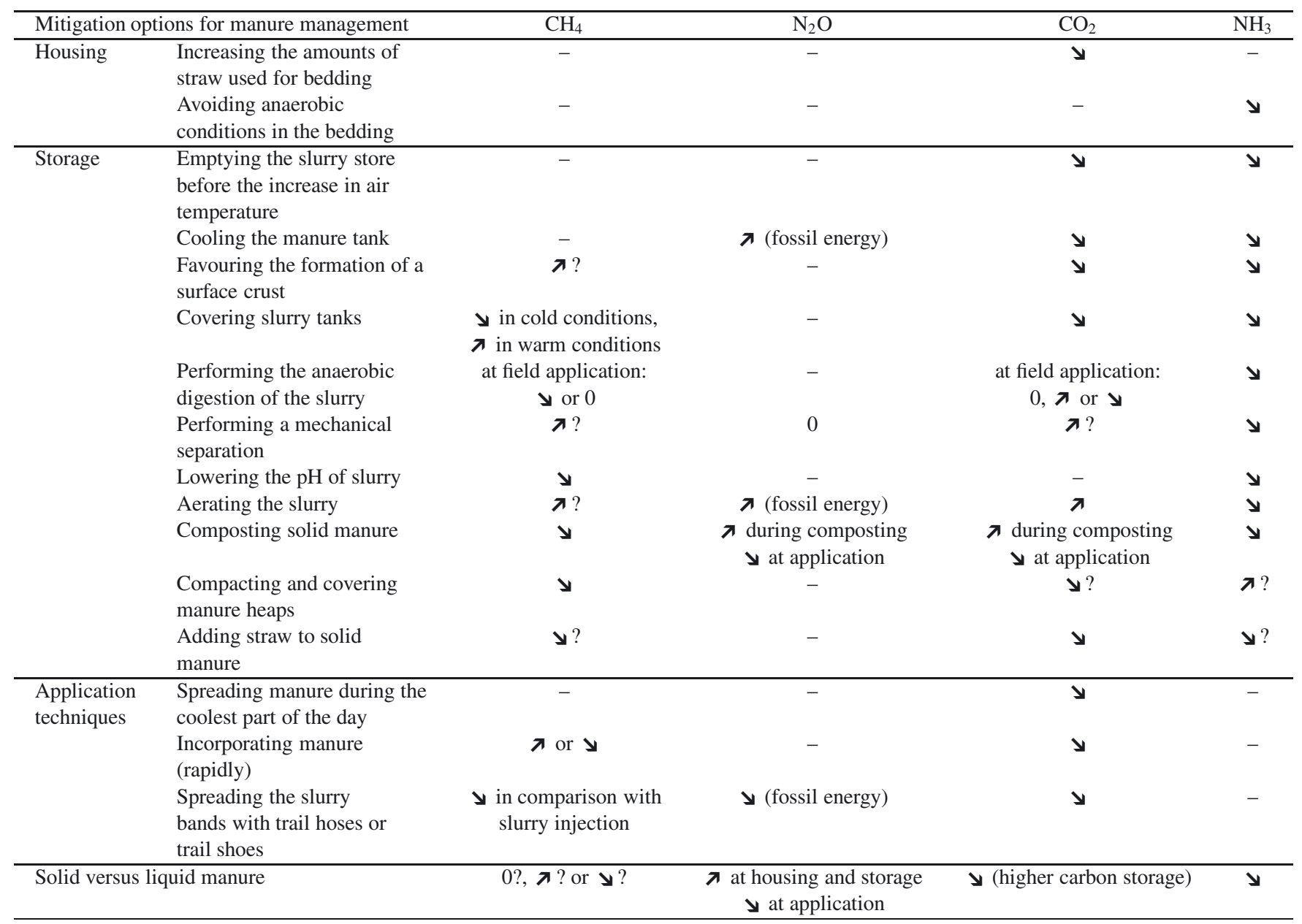

emissions from straw-based manures compared with slurrybased ones when the whole farming system is considered. It is all the more difficult to give a generalised conclusion, since GHG and $\mathrm{NH}_{3}$ emissions closely depend on the techniques and practices used for livestock housing, manure storage and manure application. Besides, an efficient comparison of solid and liquid manure systems needs to take into account the emissions generated by the production of the straw. Finally, at the whole-farm level, a change in the manure management system has implications on the balance between grassland and arable areas, these latter determining the production of straw used for the bedding.

In conclusion, Table III summarises the effects on GHG and $\mathrm{NH}_{3}$ emissions of the different mitigation options discussed for the manure handling chain. An overall reduction of GHG and $\mathrm{NH}_{3}$ emissions at the manure handling chain requires that mitigation options are implemented on all its parts, from housing to application. For housing, the reduction of $\mathrm{NH}_{3}$ and $\mathrm{CH}_{4}$ emissions may be achieved by a judicious management of the bedding, whereas among the several techniques available at the storage level, anaerobic digestion seems the most promis- ing to reduce the overall GHG emissions from storage and land spreading, without increasing $\mathrm{NH}_{3}$ emissions. At application, band spreading effectively reduces emissions, all the more since the manure is applied to arable land by trail hose and rapidly incorporated.

\subsection{Crop production}

For the crop production sub-system, the mitigation options focus on limiting $\mathrm{CO}_{2}$ and $\mathrm{N}_{2} \mathrm{O}$ emissions, which are the main gases produced at this level. The limitation of net $\mathrm{CO}_{2}$ emissions from cropping systems may be achieved either by increasing the $\mathrm{C}$ storage in soils or plants, or by slowing the return of stored $\mathrm{C}$ into the atmosphere via mineralisation (or fire). For instance, measures such as the incorporation of straw aim at enhancing the input of carbon to the soil, while measures such as reduced tillage aim at reducing the output of carbon from the soil. Mitigation options dealing with $\mathrm{N}_{2} \mathrm{O}$ emissions are mainly based on an improvement of the $\mathrm{N}$-use efficiency of crops, because $\mathrm{N}_{2} \mathrm{O}$ is generated by soil 
microorganisms largely from surplus mineral $\mathrm{N}$, which may also lead to nitrate leaching (Syväsalo et al., 2006; Kuikman et al., 2004; Smith et al., 2008). To a lesser extent, mitigation options aim to improve soil structure to limit anaerobic sites favouring $\mathrm{N}_{2} \mathrm{O}$ emissions (Ball et al., 1999). We will present the main mitigation options reducing $\mathrm{N}_{2} \mathrm{O}$ and $\mathrm{CO}_{2}$ emissions of the crop production system by considering in turn crop rotation, fertilisation and soil tillage.

\subsubsection{Crop rotation}

Increasing diversity in crop rotation is generally associated with a positive effect on $\mathrm{C}$ sequestration (West and Post, 2002), especially when legumes are introduced (INRA, 2002; Gregorich et al., 2005). Some crop species favour C storage in soils, such as crops with large deep root systems and perennial crops, which are generally regarded as allocating more $\mathrm{C}$ below-ground (Rees et al., 2005; Smith et al., 2008). On the other hand, silage maize, which is characterised by a low return of crop residues, is thought to decrease the $\mathrm{C}$ stock of soils (INRA, 2002). Perennial crops also have a beneficial effect on $\mathrm{N}_{2} \mathrm{O}$ emissions during winter (Gregorich et al., 2005) and on nitrate leaching losses (Watson et al., 2005), which have generally been shown to be smaller from perennial than from annual crops following manure application.

Organic cropping systems are generally characterised by temporary leys which alternate with arable crops. Temporary leys have a potential for soil C storage intermediate between crops and permanent grassland (Soussana et al., 2004). Prolonging the lifespan of temporary leys permits one not only to maintain their $\mathrm{C}$ storage for a longer time, but also to increase their storage capacity (INRA, 2002). Part of the additional carbon stored in the soil during the ley phase is released when it is ploughed up (Soussana et al., 2004). Ploughing of the ley results in a rapid mineralisation of soil organic matter and thus in large $\mathrm{CO}_{2}$ emissions. The release of large quantities of $\mathrm{N}$ from mineralisation of grass/clover residues may also favour nitrate leaching (Berntsen et al., 2006) and may significantly contribute to the total $\mathrm{N}_{2} \mathrm{O}$ emission from cultivated soils (Flessa et al., 2002; Vellinga et al., 2004).

Nitrate losses following grassland cultivation may be controlled by good management practices, such as delaying ploughing until late winter or spring for spring crops (Watson et al., 2005). If spring incorporation of the ley is not possible, it is advised to establish the following crop early in autumn to maximise $\mathrm{N}$ uptake during autumn (Berry et al., 2002) or to use efficient catch crops after ploughing. For instance, Eriksen et al. (2004) showed a considerable decrease in nitrate leaching when replacing the rotation "winter wheat - bare soil", following the ploughing of the ley, by spring oats and ryegrass catch crops in the two winters. More generally, cover crops or "catch crops" may be planted when the period between two main crops is rather long, with the advantage of reducing nitrate leaching after harvest of the main crop in autumn and increasing the total duration of photosynthesis (INRA, 2002). The immobilised soil nitrogen is subsequently made available after incorporation by mineralisation. Therefore, careful atten- tion to the timing and method of incorporation of the cover crop, to synchronise mineralisation with periods of high crop demand (Hu et al., 1997), is very important. However, there are still uncertainties on how decomposition and mineralisation of cover crop residues that are incorporated into soil will affect nitrate leaching over the long term (McNeill et al., 2005). For enhancing the $\mathrm{C}$ storage from cover crops it is preferable to incorporate them with reduced tillage.

\subsubsection{Fertilisation}

Mitigation options concerning fertilisation are mainly based on an improvement of the $\mathrm{N}$ efficiently used by crops to reduce mineral $\mathrm{N}$ accumulation in the soil, which may generate both $\mathrm{N}_{2} \mathrm{O}$ emissions and nitrate leaching.

\subsubsection{Improving $N$-use efficiency}

Practices improving N-use efficiency consist of synchronising $\mathrm{N}$ inputs with crop growth and crop uptake, such as, for instance, adjusting application rates with crop needs or avoiding time delays between $\mathrm{N}$ application and plant $\mathrm{N}$ uptake (improved timing). However, these mitigation measures reviewed by Monteny et al. (2006) were mainly devised for farming systems using mineral fertilisers and not for organic systems where the supply of soil mineral $\mathrm{N}$ is the sum of biological fixation from legumes, and direct inputs of mineral $\mathrm{N}$ from atmospheric deposits and manure, plus mineralisation from soil organic matter and other organic materials (crop residues, manure).

$\mathrm{N}$ fixed by legumes represents the major source of $\mathrm{N}$ inputs into organic cropping systems but its quantification is very uncertain (Nicholas et al., 2004), because its magnitude is regulated by changes in soil inorganic $\mathrm{N}$ and competition from associated grasses (Ledgard and Steele, 1992). For instance, the percentage of legumes in a ley decreases with increasing manure application (Hansen, 1996). This feedback mechanism has, however, the advantage of limiting the $\mathrm{N}$ inputs to legume/grass soil and consequently regulating the potential for N losses to watercourses or air (Syväsalo et al., 2006). Besides, according to Rochette and Janzen (2005), much of the increase in soil $\mathrm{N}_{2} \mathrm{O}$ emissions in legume crops would be attributable to the $\mathrm{N}$ released from root exudates during the growing season and from decomposition of crop residues after harvest, rather than from biological $\mathrm{N}$ fixation per se. Carter and Ambus (2006) also found that recently fixed $\mathrm{N}$ released via easily-degradable clover residues was a minor source of $\mathrm{N}_{2} \mathrm{O}$ in a grass-clover grassland.

The soil mineral nitrogen coming from the mineralisation of soil organic matter is also hard to predict, since the actual amount and timing of the mineralisation is influenced by a number of factors including soil moisture, aeration and temperature, the nature and accessibility of the organic matter, previous fertilisation, intensity and timing of cultivation, and cropping patterns (Stockdale and Rees, 1995; Rasmussen et al., 1998; Berry et al., 2002). Matching nitrogen supply from 
the mineralisation of soil organic matter with crop demand is thus a difficult exercise.

In organic farming, improvements in N-use efficiency are particularly related to an effective use of manures as nutrient resources. This effective management of manure and slurry must take into account that nutrients in farmyard manure are available at a slower rate for plant uptake than from slurry (Watson et al., 2005) and that uncomposted manure contains more readily available $\mathrm{N}$ than composted manure (Berry et al., 2002). As manures vary widely in composition, depending on feed composition, quality and quantity of bedding material, length of storage and storage conditions (Shepherd, 2000; Watson et al., 2002), manure analysis may help to predict its available $\mathrm{N}$. For instance, $\mathrm{N}$ content and the $\mathrm{C} / \mathrm{N}$ ratio of animal wastes are highly correlated with the $\mathrm{N}$ mineralisation rate (Morvan et al., 2006) and they may be used to predict it. The use of agronomic models to provide decision support systems or appropriate management guidelines for organic $\mathrm{N}$ fertilisation is promising but still needs further development (David et al., 2005; Morvan et al., 2006). These models could help to improve manure and slurry use; for instance, by determining the type of manure most beneficial to the different crops of the rotation over longer periods than a single crop or growing season to ensure both short-term productivity and long-term sustainability (Watson et al., 2005). Future improvements in $\mathrm{N}$ utilisation within organic systems could also be made by breeding crops with traits that improve the capture of available $\mathrm{N}$ and the efficiency with which is it converted to yield (Berry et al., 2002).

Improved timing of manure application may also help to prevent nitrate leaching, which generally occurs when large amounts of nitrate in the soil profile coincide with a period of high drainage (Di and Cameron, 2002). In areas with lighttextured soils, manures applied in spring pose a smaller risk for leaching than when they are applied to bare soil in autumn (McNeill et al., 2005). Splitting the annual N application rates was also shown to reduce nitrate leaching losses for pasture systems, by improving the synchrony between the pasture $\mathrm{N}$ demand and supply (Di and Cameron, 2002). Composting the manure may also be effective at reducing nitrate leaching losses, which were shown to be lower from the application of composted manure compared with its raw materials (Basso and Ritchie, 2005).

More generally, strategies reducing $\mathrm{N}$ leaching will also limit $\mathrm{N}_{2} \mathrm{O}$ emissions. Besides, modelling studies showed that improving farm efficiency of $\mathrm{N}$ management would reduce overall GHG emissions from conventional as well as from organic dairy farms (Schils et al., 2006; Olesen et al., 2006). However, $\mathrm{N}$ budgets for organic farms are less reliable than those for conventional farms, particularly because $\mathrm{N}$ fixation represents the predominant $\mathrm{N}$ input source for organic farms (see e.g. Steinshamn et al., 2004) and its estimation remains highly uncertain even with the use of empirical models. Besides, Olesen et al. (2006) indicated that the $\mathrm{N}$ efficiency is strongly affected by the ratio of crop to animal products in the farm output. Further investigations are therefore necessary to confirm this relationship between farm $\mathrm{N}$ efficiency and $\mathrm{GHG}$ emissions for organic dairy farms.

\subsubsection{Timing the effluent application with soil wetness}

Another strategy, proposed by de Klein and Eckard (2008) to limit $\mathrm{N}_{2} \mathrm{O}$ emissions resulting from fertilisation, is the timing of effluent application in relation to soil wetness. $\mathrm{N}_{2} \mathrm{O}$ emissions were indeed shown to be higher when the slurry was applied to wet soil compared with drier soil (Saggar et al., 2004).

\subsubsection{Sequestering $C$ through an improved fertilisation}

Manure management also affects soil organic carbon sequestration in different ways, the two main ones being biomass production and $\mathrm{N}$ availability. Firstly, fertilisation increases the primary productivity of crops and therefore the quantities of above- and below-ground residues added into soil in unharvested plant parts (Rees et al., 2005). However, the decomposition rates of the crop residues (mineralised into $\mathrm{CO}_{2}$ ) could also be increased for high fertilisation inputs (Rees et al., 2005). Secondly, soil N availability is one of the main factors affecting humus formation in agricultural soils (Christopher and Lal, 2007). Furthermore, manures are a source of $\mathrm{C}$ per se, and the fate of their $\mathrm{C}$ in soil (mineralised versus humified) depends particularly on the biochemical characteristics of their organic matter (e.g. Morvan et al., 2006), and therefore on the cattle's diet and on the straw characteristics. As stated by Christopher and Lal (2007): "the challenge of sequestering $\mathrm{C}$ in agricultural soils is to increase the concentration of humus while producing good crop yields and maintaining low concentrations of $\mathrm{N}$ in soil solution and discharging waters". The hypothesis put forward by Smith et al. (2000) that the application of farm manures to arable soils can increase the soil carbon stock to a greater extent than application to grasslands was questioned by Soussana et al. (2004).

\subsubsection{Soil tillage}

Ploughing is an efficient practice for weed management in organic cropping systems. However, soil tillage stimulates the decomposition of soil organic matter, particularly by disrupting soil aggregates (Balesdent et al., 2000).

\subsubsection{Limiting soil tillage}

Limiting soil disturbance by reduced (shallow) tillage or no tillage therefore decreases the decomposition rate of soil organic carbon (Smith et al., 2000; Rees et al., 2005). Depending on the study concerned, reduced tillage was as effective as no tillage at storing $\mathrm{C}$ in soil (INRA, 2002) or it did not induce significant change in soil organic carbon (Kern and Johnson, 1993). Effectiveness of conversion to conservation tillage on soil organic carbon sequestration also depends on soil and climatic factors such as texture, temperature and water availability (Lal, 2004a; Rees et al., 2005). For instance, 
light-textured and well-drained soils in moist and cool climates would sequester more soil organic carbon than clayey and poorly-drained soils (Lal, 2004b). Reduced tillage would also be more effective where relatively high soil carbon contents occur simultaneously with relatively high decomposition rates (Vleeshouwers and Verhagen, 2002).

The permanence of the tillage practices is another determining factor in soil carbon sequestration, because soil carbon sequestered in arable soils is impermanent and is lost more rapidly than it accumulates (Freibauer et al., 2004). Agricultural soils that are tilled every few years may contain more carbon than the same soils cultivated every year (Smith et al., 1997), but even a single ploughing can drastically accentuate emissions of $\mathrm{CO}_{2}$ from soil, because of an increase in the rate of mineralisation (Reicosky et al., 1999).

One must also take into account that the absence of tillage may lead to higher $\mathrm{N}_{2} \mathrm{O}$ emissions than conventional tillage, due to larger soil aggregates, low gas diffusivity and greater water retention near the soil surface making the soil less aerobic (Ball et al., 1999; Smith et al., 2001). The results of studies comparing $\mathrm{N}_{2} \mathrm{O}$ emissions from conventional versus reduced tillage are, however, conflicting (see e.g. Holland, 2004; Smith and Conen, 2004), like those of studies comparing manure incorporation into the soil (as previously reported).

Moreover, the differences in $\mathrm{N}_{2} \mathrm{O}$ fluxes between the two tillage systems are likely to change over time. Six et al. (2004) showed increased $\mathrm{N}_{2} \mathrm{O}$ fluxes in the first 10 years of adoption of no-tillage, but lower $\mathrm{N}_{2} \mathrm{O}$ fluxes in humid climates in notill than conventional till after 20 years. These results can be explained by the transient lower crop yields and the greater soil water content generally observed in recently established no-till systems (Six et al., 2004), or by an improvement of the soil structure with time (Holland, 2004). Conversely, methane uptake was reported to be significantly increased under notillage (Six et al., 2004). Finally, considering the three GHG fluxes together, Six et al. (2004) found that no-tillage leads to an increase in net global warming potential during the first 10 years, but to a strong decrease after 20 years of adoption in humid climates.

West and Post (2002) and West and Six (2007) found greater $\mathrm{C}$ sequestration for a decrease in tillage intensity as compared with an increase in rotation complexity, but they emphasised that increase in soil $\mathrm{C}$ following a change in rotation complexity may occur over a slightly longer period of time. The sequestration of soil organic carbon resulting from a change in tillage may also depend on the crop species (Wright et al., 2007).

None of these results take into account the direct machinery energy consumption. The cultivation of soils by ploughing is the most fuel-consuming process in the production of arable crops (Holland, 2004). Conservation tillage has the additional benefit of saving fuel and therefore of limiting $\mathrm{CO}_{2}$ emissions (see e.g. Filipovic et al., 2006), even if systems based upon conservation tillage may require additional operations such as the creation of a stale seedbed (Holland, 2004).

\subsubsection{Avoiding soil compaction}

Soil compaction by tractor wheels and tillage machinery may increase $\mathrm{N}_{2} \mathrm{O}$ emission (Ball et al., 1999) by favouring the development of anaerobic zones within some of the soil structural units as a result of the loss of air-filled macropores (McNeill et al., 2005). Therefore, avoiding compaction by traffic and tillage may help to reduce $\mathrm{N}_{2} \mathrm{O}$ emissions, especially since compaction has a great effect on yield (Hansen, 1996; Stockdale et al., 2001) and thus on C storage and nitrate leaching.

\subsubsection{Incorporating crop residues}

Incorporation of crop residues tends to increase soil organic matter, thus storing $\mathrm{C}$ in the soil, but $\mathrm{N}$-rich crop residues may stimulate rapid denitrification and associated nitrous oxide emissions, even in coarse-textured soils (Velthof et al., 2002). From a $\mathrm{N}_{2} \mathrm{O}$ mitigation point of view, incorporating residues with low $\mathrm{N}$ content is better than a homogeneous mixing of $\mathrm{N}$ rich materials into the soil (Ambus et al., 2001). Incorporation of $\mathrm{N}$-rich, low $\mathrm{C} / \mathrm{N}$ ratio residues leads to rapid mineralisation and a large rise in soil mineral $\mathrm{N}$, while residues low in $\mathrm{N}$, such as cereal straw, can lead to net immobilisation of $\mathrm{N}$ in the short to medium term (Watson et al., 2002). On livestock farms, however, straw is more likely to be used for bedding. Moreover, based on a review of published Canadian studies, Gregorich et al. (2005) concluded that ploughing manure or crop stubble into the soil in the autumn led to higher levels of $\mathrm{N}_{2} \mathrm{O}$ production $\left(2.41 \mathrm{~kg} \mathrm{~N}^{-\mathrm{N}_{2}} \mathrm{O} \mathrm{ha}^{-1}\right.$ year $\left.^{-1}\right)$ than if residues were left on the soil surface $\left(1.19 \mathrm{~kg} \mathrm{~N}^{-\mathrm{N}_{2}} \mathrm{Oha}^{-1} \mathrm{year}^{-1}\right)$. Mineralisation of $\mathrm{N}$ from crop residues may also result in nitrate leaching, depending on the quantity of $\mathrm{N}$ in the plant material and its $\mathrm{C} / \mathrm{N}$ ratio (Berry et al., 2002), on the synchrony between $\mathrm{N}$ release and plant demand (Eriksen et al., 2006), and on soil texture.

The $\mathrm{N}$ content of crop residues also influences soil $\mathrm{C}$ sequestration. Incorporation of crop species producing residues with high $\mathrm{C} / \mathrm{N}$ ratios (such as wheat) was shown to favour $\mathrm{C}$ sequestration compared with residues with low $\mathrm{C} / \mathrm{N}$ ratios, which stimulated decomposition of native soil organic matter (Wright et al., 2007). Nevertheless, even low $\mathrm{C} / \mathrm{N}$ ratio materials are beneficial for $\mathrm{C}$ sequestration after their incorporation (Rees et al., 2005).

In any case, crop residues should not be burned to avoid emissions of aerosols (Hays et al., 2005) and of $\mathrm{CO}_{2}$, resulting in C losses for the system (Lal, 2004b).

In conclusion, Table IV summarises the effects on GHG and $\mathrm{NH}_{3}$ emissions of the different mitigation options discussed for crop production. The main mitigation options concern the introduction of perennial crops or the longer duration of temporary leys, a reduction of the tillage or the improvement of crop N-use efficiency through effective management of manure and slurry, by growing catch crops or by delaying the ploughing of leys. The long-term effects of these mitigation options are still uncertain because of the difficulty of predicting and controlling the $\mathrm{C}$ and $\mathrm{N}$ dynamics of organic matter in soils. 
Table IV. Effects on greenhouse gas and ammonia emissions of mitigation options at the crop production stage.

\begin{tabular}{|c|c|c|c|c|c|}
\hline \multicolumn{2}{|c|}{ Mitigation options for crop production } & $\mathrm{CH}_{4}$ & $\mathrm{~N}_{2} \mathrm{O}$ & $\mathrm{CO}_{2}$ & $\mathrm{NH}_{3}$ \\
\hline \multirow{4}{*}{ Crop rotation } & Increasing diversity in crop rotation & - & - & $y$ & - \\
\hline & Introducing perennial crops & - & $y$ & y & - \\
\hline & $\begin{array}{l}\text { Prolonging the lifespan of } \\
\text { temporary leys }\end{array}$ & - & $-\lambda$ after ploughing & $\boldsymbol{y} \boldsymbol{\nearrow}$ after ploughing & - \\
\hline & Cultivating catch crops & - & $\boldsymbol{y}$ at short term $\boldsymbol{\lambda}$ ? at long term & $\boldsymbol{y}$ at short term $\boldsymbol{\nearrow}$ ? at long term & - \\
\hline $\begin{array}{l}\text { Genetic } \\
\text { selection }\end{array}$ & $\begin{array}{l}\text { Breeding crops improving } \mathrm{N} \\
\text { use efficiency }\end{array}$ & - & $y ?$ & - & - \\
\hline \multirow{3}{*}{ Fertilisation } & $\begin{array}{l}\text { Synchronizing } \mathrm{N} \text { inputs with } \\
\text { crop uptake }\end{array}$ & - & $\mathbf{y}$ & - & - \\
\hline & $\begin{array}{l}\text { Timing effluent application } \\
\text { with soil wetness }\end{array}$ & - & $\mathbf{y}$ & - & - \\
\hline & Improving the fertilisation & - & $\pi ?$ & $\boldsymbol{y}$ ? or $\boldsymbol{\lambda}$ ? & - \\
\hline \multirow{3}{*}{ Soil tillage } & Reducing tillage & $\pi ?$ & 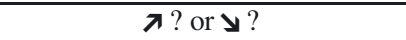 & $y$ & - \\
\hline & Avoiding soil compaction & - & $y$ & $y$ & - \\
\hline & Incorporating crop residues & - & $\pi ?$ & $y$ & - \\
\hline
\end{tabular}

\subsection{Grasslands}

In this section we will discuss conversion from arable to grassland and review mitigation options applicable to grazing management.

\subsubsection{Conversion from arable to grassland}

Several studies comparing farmland management options in Europe have indicated that conversion from arable to grassland (and to a lesser extent from temporary grassland to permanent grassland) provides high soil $\mathrm{C}$ sequestration potential (INRA, 2002; Smith, 2004). The results of Ammann et al. (2007) suggest, however, that the conversion of arable land to managed grassland has a positive effect on the carbon balance during the first 3 years only if the system receives nitrogen inputs. A moderate increase in $\mathrm{N}$ supply to nutrient-poor permanent grasslands has also been shown in long-term surveys to increase grassland topsoil organic carbon stocks, except for nutrientpoor grasslands developed on organic soils (Soussana et al., 2004). To be effective, the conversion from arable to grassland should remain permanent, because the ploughing under of grassland results in large $\mathrm{CO}_{2}$ and $\mathrm{N}_{2} \mathrm{O}$ emissions (Vellinga et al., 2004). Also, carbon losses are much faster after returning grassland to arable use than the build-up of soil carbon when establishing grassland (Soussana et al., 2004).

Until recently, the general assumption was that soil carbon fluxes were in balance in permanent pasture, i.e. in the absence of changes in environmental factors and in land use and management, an equilibrium value was reached for all soil organic C pools (e.g. Freibauer et al., 2004; Lovett et al., 2006). However, the recent results of Soussana et al. (2007) do not confirm this concept of carbon sink saturation for permanent seminatural grasslands, which displayed net carbon storage. Their study indicated that extensively managed (i.e. semi-natural) but N-rich grasslands may store more carbon than highly intensive (i.e. newly sown grass-clover mixtures) grasslands.
Conversion of annual fodder or cereal crops into temporary or permanent grasslands or conversion of temporary grassland into permanent grassland means an increasing proportion of grass in the diet of animals, which often corresponds with an extensification of the livestock production at the farm level.

\subsubsection{Grazing management}

\subsubsection{Livestock density}

We will consider here the possible mitigation options induced by the management of the livestock density with a constant herd size, and not the limitation of emissions resulting from a reduction of the number of animals on the farm. Under continuous grazing systems, the effect of stocking rate on methane production per animal is not consistent. For instance, McCaughey et al. (1997) observed a decrease in absolute $\mathrm{CH}_{4}$ emissions $\left(\mathrm{g} \mathrm{d}^{-1}\right)$ and $\mathrm{CH}_{4}$ yield $\left(\mathrm{CH}_{4}\right.$ energy loss as a percentage of gross energy intake, \% of GEI) with increasing stocking rates of steers ( 1.1 versus 2.2 steer ha $^{-1}$ ), while Pinares-Patino et al. (2007) found only a reduction in the $\mathrm{CH}_{4}$ yields (\% GEI) and not in the absolute $\mathrm{CH}_{4}$ emissions per animal with increasing stocking rates of heifers (1.1. versus $\left.2.2 \mathrm{LU} \mathrm{ha}^{-1}\right)$. When pastures were rotationally grazed, stocking rates had no effect on $\mathrm{CH}_{4}$ production (McCaughey et al., 1997).

Increasing livestock density seems not to be an efficient mitigation option, since the nitrogen surplus increases with increasing stocking density (Stockdale et al., 2001; Dalgaard et al., 2002). It is therefore likely to enhance the potential for $\mathrm{N}_{2} \mathrm{O}$ losses from urine and dung excreted during grazing, especially since the increased trampling of grazing animals causes soil compaction and thus an increase in the number of anaerobic sites on the soil, which in turn may favour $\mathrm{N}_{2} \mathrm{O}$ emissions (Oenema et al., 1997). The surplus nitrogen may also be lost by nitrate leaching: Eriksen et al. (1999) observed a tendency towards increased nitrate leaching losses with increasing stocking density. Moreover, modelling results from Soussana et al. (2004) indicated that the magnitude of the C 
Table V. Effects on greenhouse gas and ammonia emissions of mitigation options for grasslands.

\begin{tabular}{|c|c|c|c|c|c|}
\hline \multicolumn{2}{|c|}{ Mitigation options for grasslands } & $\mathrm{CH}_{4}$ & $\mathrm{~N}_{2} \mathrm{O}$ & $\mathrm{CO}_{2}$ & $\mathrm{NH}_{3}$ \\
\hline Land use & $\begin{array}{l}\text { Permanent conversion from arable to } \\
\text { grassland (to a less extent from temporary to } \\
\text { permanent grassland) }\end{array}$ & - & - & ע & - \\
\hline \multirow{2}{*}{$\begin{array}{l}\text { Grazing } \\
\text { management }\end{array}$} & Increasing livestock density & $\mathbf{y}$ ? or 0 ? & $\pi ?$ & $\pi ?$ & - \\
\hline & Selective grazing associated with grass maturity & צ? & - & - & - \\
\hline
\end{tabular}

sink of grazed grasslands declined with the mean annual stocking rate. On the other hand, a drastic reduction in livestock density is also not recommended, since Allard et al. (2007) showed that grassland management methods that abruptly reduced grazing pressure (1.2 to $0.6 \mathrm{LU} \mathrm{ha}^{-1}$ year $^{-1}$ ) and fertiliser input ( 80 to $0 \mathrm{~kg} \mathrm{~N} \mathrm{ha}^{-1}$ year $^{-1}$ ) gradually reduced the $\mathrm{C}$ storage potential of the grassland.

\subsubsection{Grazing system}

There is limited information with regard to the effects of rotational grazing versus continuous grazing on $\mathrm{CH}_{4}$ production. For steers, McCaughey et al. (1997) observed that at low stocking rates $\left(1.1\right.$ steer ha $\left.{ }^{-1}\right), \mathrm{CH}_{4}$ production $\left(\mathrm{L} \mathrm{ha}^{-1} \mathrm{~d}^{-1}\right)$ was $9 \%$ lower for rotational grazing than continuous grazing.

Selective grazing which is associated with grass maturity is likely to limit $\mathrm{CH}_{4}$ emissions. Pinares-Patino et al. (2003) showed that the grazing of grass at early heading induced a decrease of $10 \%$ in $\mathrm{CH}_{4}$ emissions compared with the grazing of the same grass at a later stage of maturity when digestibility was lower. Nevertheless, $\mathrm{CH}_{4}$ emissions are generally more determined by feed intake rather than feed digestibility (McCaughey et al., 1999; Pinares-Patino et al., 2007), an increase in feeding level inducing lower $\mathrm{CH}_{4}$ losses as a fraction of gross energy intake (Boadi et al., 2004).

As EU 1804/99 regulation specifies that the rearing systems for herbivores are to be based on maximum use of "pasturage", we will not discuss mitigation options affecting the length of the grazing period. This maximum use of grasslands should, however, be managed in order to prevent adverse effects on soil (compaction) or vegetation (through overgrazing), which affect $\mathrm{N}_{2} \mathrm{O}$ and $\mathrm{CH}_{4}$ emissions (soil compaction) or nitrate leaching (scarce vegetation), as discussed previously.

In conclusion, Table V summarises the effects on GHG and $\mathrm{NH}_{3}$ emissions of the different mitigation options discussed for grasslands. The main mitigation option consists of converting arable to grassland, especially permanent grasslands which allow $\mathrm{C}$ sequestration. Concerning grazing management, a higher livestock density may lead to a decrease in $\mathrm{CH}_{4}$ emissions by the grazing animals, but to an increase in $\mathrm{N}_{2} \mathrm{O}$ emissions from their excreta and to a decrease in the $\mathrm{C}$ stored by the grasslands. In the same way, selective grazing associated with lower stocking density allows a decrease in $\mathrm{CH}_{4}$ emissions through an increasing digestibility of intake compared with a more complete use of grass.
Table VI. Effects on greenhouse gas and ammonia emissions of mitigation options for other prospects.

\begin{tabular}{|c|c|c|c|c|c|}
\hline Mitigation & ptions & $\mathrm{CH}_{4}$ & $\mathrm{~N}_{2} \mathrm{O}$ & $\mathrm{CO}_{2}$ & $\mathrm{NH}_{3}$ \\
\hline Arable field & Introducing hedgerows or tree belts & - & - & ע & ע \\
\hline Farm scale & Increasing energy efficiency & - & - & ע & - \\
\hline Crop & Producing plant oil & - & - & ע & - \\
\hline
\end{tabular}

\subsection{Other prospects}

In this paragraph we give some leads on other types of mitigation options that may apply to organic mixed crop-dairy systems. Their effects on GHG and $\mathrm{NH}_{3}$ emissions are summarised in Table VI. Hedgerows or tree belts may be introduced in arable field margins to store carbon, and to recapture part of the $\mathrm{NH}_{3}$ emitted into the air by the farm (Theobald et al., 2002). Increasing the energy efficiency is also a way to reduce $\mathrm{CO}_{2}$ emissions. Diesel savings may be achieved by technological solutions (e.g. better mechanical efficiency of tractors, use of wind or solar energy instead of fossil fuel) or by improved farm machinery management (e.g. optimised field operations and work planning, see e.g. Dyer and Desjardins 2003; Couvreur, 2006). In the context of organic mixed cropdairy systems, the production of biomass for energy (bioenergy crops) is not feasible on a large scale. However, the production of small quantities of plant oil that can be used as fuel and which also provide oil-seed cakes for livestock feeding (see e.g. Brunschwig and Lamy, 2006) is worth studying, though these crops should not be grown in preference to pastures.

\section{DISCUSSION}

As discussed at the beginning of this article, to judge the appropriateness of mitigation options, it is essential to assess their impact on the carbon and nitrogen cycles at the wholefarm level. However, as highlighted in this review, it is far from easy because each mitigation option involves trade-offs between gases, and because there are often interactions and feedbacks among mitigation options. The choice of a set of mitigation options will therefore rely on the careful assessment of the balance between their beneficial and adverse effects. The establishment of this balance should consider not only the overall emissions of GHG and $\mathrm{NH}_{3}$ resulting from the implementation of the chosen mitigation options (including fuel 
Table VII. General characteristics of whole-farm greenhouse gas models (adapted from Schils et al., 2007).

\begin{tabular}{lccc}
\hline & DairyWise & FarmGHG & SIMS \\
\hline Authors & Schils et al. (2006) & Olesen et al. (2006) & Del Prado et al. (2006) \\
Model type & Empirical & Empirical & Semi-mechanistic \\
$\mathrm{CH}_{4}$ and $\mathrm{N}_{2} \mathrm{O}$ emissions & $\mathrm{x}$ & $\mathrm{x}$ & $\mathrm{S}$ \\
$\mathrm{CO}_{2}$ emissions & $\mathrm{x}$ & $\mathrm{x}$ & $\mathrm{x}$ \\
$\mathrm{C}$ sequestration & & $\mathrm{x}$ & $\mathrm{x}$ \\
$\mathrm{NH}_{3}$ and $\mathrm{NO}_{3}$ emissions & $\mathrm{x}$ & $\mathrm{x}$ & $\mathrm{x}$ \\
Pre-chain emissions & $\mathrm{x}$ & & $\mathrm{x}$ \\
Animal welfare & & $\mathrm{x}$ \\
Biodiversity & & $\mathrm{x}$ \\
Soil quality & & $\mathrm{x}$ & $\mathrm{x}$ \\
\hline
\end{tabular}

carbon costs for farm operations), but also their environmental and agronomic side effects. GHG and $\mathrm{NH}_{3}$ mitigation measures often have accompanying benefits on other environmental components than global warming. For instance, $\mathrm{C}$ storage in soils has several unintended beneficial effects on soil fertility and water quality (see e.g. Lal, 2004a) and hedgerows used to store $\mathrm{C}$ in vegetation have many other valuable functions (see e.g. Marshall and Moonen, 2002) such as windbreaks or habitat for wild plants and animals. In addition to the consideration of environmental side effects, it is important to consider the effects of mitigation measures on animal welfare, which is another objective of organic farming. Animal welfare may be affected in several ways: e.g. through the feeding, housing conditions (type of bedding), presence of shelters (trees) on the pasture, length of the grazing period, etc. We will not consider in this article the economic and social aspects of the implementation of mitigation options (see e.g. Smith et al., 2007).

In this article we have examined the effects of mitigation options at the farm level. But to draw conclusions about their positive effects on global change, it seems important to consider also the emissions generated by the production and transport of materials needed to implement the mitigation measures (e.g. purchased concentrates, biogas plant). Besides, mitigation options also have to be devised for the transport of dairy farm products (exported from the farm). To reduce fuel consumption, an off-farm strategy consists, for instance, of moving to a more regionally-based economy, in which the producer and consumer are brought closer together (Johnson et al., 2007).

Another factor to take into consideration is the period of time needed to establish the balance between beneficial and adverse effects of mitigation options. GHG (especially $\mathrm{N}_{2} \mathrm{O}$ ) and $\mathrm{NH}_{3}$ emissions vary greatly over time, particularly because of the influence of meteorological conditions on physicochemical and biological reactions governing them. The effectiveness of a mitigation measure will thus show strong year-to-year variations. Furthermore, the delay between the implementation of a mitigation measure and the reduction of the emissions will greatly vary between mitigation options. For instance, an improvement in the method of applying manure will have an immediate effect on $\mathrm{NH}_{3}$ emissions, whereas a change in land management or in soil tillage affecting the soil properties (and thus soil carbon sequestration and $\mathrm{N}_{2} \mathrm{O}$ emis- sions) will probably involve a time scale of several years. Also, the kinetics of carbon accumulation following change in land use or grassland management are non-linear, i.e. they are more rapid during the early years after adopting a practice which enhances accumulation (INRA, 2002). The balance of a mitigation measure may thus change with time. For instance, as discussed above, Six et al. (2004) found that zero tillage leads to an increase in net global warming potential during the first 10 years, but to a strong decrease after 20 years of adoption in humid climates.

The soil and climatic context of each mixed crop-dairy system will be important for determining the most effective set of mitigation options. The soil characteristics, particularly its hydromorphy, will play an important role in the $\mathrm{N}_{2} \mathrm{O}$ emissions and in soil organic matter mineralisation; it will also affect the best time for manure application or soil tillage (trafficability), and even the balance between grassland and arable areas. This balance may also determine the amount of straw in the manure but it is not clear whether slurry or farmyard manure will be more beneficial for global warming.

Decision support tools would be useful to assess the balance of different sets of mitigation options by taking into consideration trade-offs, interaction and feed-back among practices for different time scales and at the farm level, and by evaluating their impact upon environmental and agronomic components. Simulation models already exist on the dairy farm scale (reviewed by Schils et al., 2007; Tab. VII) but they still need improvements to accurately evaluate mitigation options from organic dairy farms. In particular, GHG emissions resulting from legume incorporation and from deep litter mats need further research to be accurately modelled. Simulation modelling, combining biophysical and decisional models, would also help farmers with their management decisions at both strategic and tactical levels.

Besides, the assessment of mitigation options (and the validation of models) is only possible if accurate measurements of the GHG and $\mathrm{NH}_{3}$ emissions or of the carbon storage are available. Measuring greenhouse gas emissions for the different farm components, however, presents serious difficulties (see e.g. the review of McGinn, 2006), particularly because emissions are characterised by a high spatial and temporal variability. Measurements are necessary, not only to assess the efficiency of mitigation options but also to identify all the 
major sources of GHG emissions of mixed crop-dairy systems, some of which may currently be underestimated, such as, for instance, ditches or fresh heaps of maize silage (Hensen et al., 2006).

\section{CONCLUSION}

The most promising mitigation options are firstly measures that increase energy efficiency or fuel savings, because they are beneficial in any case. Secondly, techniques improving efficiency of $\mathrm{N}$ management at field and farm levels should also be promoted because they affect not only $\mathrm{N}_{2} \mathrm{O}$ and $\mathrm{NH}_{3}$ emissions, but also nitrate leaching. A better use of $\mathrm{N}$ at the farm level is, however, confronted by difficulties in organic mixed crop-dairy systems, either to optimise the total $\mathrm{N}$ intake of the livestock or to improve the $\mathrm{N}$-use efficiency of crop and grass production. For instance, the management of the $\mathrm{N}$ content of the diet has to cope with the varying and unpredictable proportion of legumes in pastures, and the mineral $\mathrm{N}$ content of the soil is difficult to control through application of manures and incorporation of crop residues. Thirdly, biogas production through anaerobic digestion of manure seems a promising and efficient way to mitigate GHG emissions, but the profitability of this expensive investment needs to be studied in the local context before its implementation. Last but not least, the way the farmer will implement the mitigation options, i.e. his practices, will be a determining factor in the reduction of GHG and $\mathrm{NH}_{3}$ emissions. Some techniques such as composting may or may not be considered as a mitigation option, depending on the farmer's practices.

Options aiming to reduce $\mathrm{GHG}$ and $\mathrm{NH}_{3}$ emissions result in numerous trade-offs between air pollutant emissions and nutrient flows that may occur in all the components of the farming system, and that may involve time scales of decades or even more. Before its implementation, a mitigation option should therefore be assessed in the context of the whole farming system or even larger by including pre- and post-chains, at least on the time scale of the crop rotation and if possible, by considering other issues than global warming, e.g. water quality, soil fertility, animal welfare, biodiversity, etc. The interactions and feedback that can take place among a set of mitigation options also have to be considered. The determination of the most effective set of mitigation options would thus benefit from the development of decision support tools based on dynamic models of the $\mathrm{C}$ and $\mathrm{N}$ cycles of the whole farming system.

\section{REFERENCES}

Ademe, Aile, Solagro, Trame (2006) La méthanisation à la ferme, Paris, p. 16.

Allard V., Soussana J.-F., Falcimagne R., Berbigier P., Bonnefond J.M., Ceschia E., D'hour P., Henault C., Laville P., Martin C., PinaresPatino C. (2007) The role of grazing management for the net biome productivity and greenhouse gas budget $\left(\mathrm{CO}_{2}, \mathrm{~N}_{2} \mathrm{O}\right.$ and $\left.\mathrm{CH}_{4}\right)$ of semi-natural grassland, Agr. Ecosyst. Environ. 121, 47-58.

Ambus P., Jensen E.S., Robertson G.P. (2001) Nitrous oxide and Nleaching losses from agricultural soil: Influence of crop residue particle size, quality and placement, Phyton-Ann. REI Bot. 41, 7-15.
Ammann C., Flechard C.R., Leifeld J., Neftel A., Fuhrer J. (2007) The carbon budget of newly established temperate grassland depends on management intensity, Agr. Ecosyst. Environ. 121, 5-20.

Amon B., Amon T., Alt C., Moitzi G., Boxberger J. (2001a) Nitrous oxide emissions from cattle production systems and mitigation options, Phyton-Ann. REI Bot. 41, 17-28.

Amon B., Amon T., Boxberger J., Alt C. (2001b) Emissions of $\mathrm{NH}_{3}$, $\mathrm{N}_{2} \mathrm{O}$ and $\mathrm{CH}_{4}$ from dairy cows housed in a farmyard manure tying stall (housing, manure storage, manure spreading), Nutr. Cycl. Agroecosyst. 60, 103-113.

Amon B., Kryvoruchko V., Amon T., Zechmeister-Boltenstern S. (2006) Methane, nitrous oxide and ammonia emissions during storage and after application of dairy cattle slurry and influence of slurry treatment, Agr. Ecosyst. Environ. 112, 153-162.

Bahn M., Knapp M., Garajova Z., Pfahringer N., Cernusca A. (2006) Root respiration in temperate mountain grasslands differing in land use, Global Change Biol. 12, 995-1006.

Balesdent J., Chenu C., Balabane M. (2000) Relationship of soil organic matter dynamics to physical protection and tillage, Soil Till. Res. 53, 215-230.

Ball B.C., Scott A., Parker J.P. (1999) Field $\mathrm{N}_{2} \mathrm{O}, \mathrm{CO}_{2}$ and $\mathrm{CH}_{4}$ fluxes in relation to tillage, compaction and soil quality in Scotland, Soil Till. Res. 53, 29-39.

Basso B., Ritchie J.T. (2005) Impact of compost, manure and inorganic fertilizer on nitrate leaching and yield for a 6-year maize-alfalfa rotation in Michigan, Agr. Ecosyst. Environ. 108, 329-341.

Beauchemin K.A., Kreuzer M., O’Mara F., McAllister T.A. (2008) Nutritional management for enteric methane abatement: a review, Aust. J. Exp. Agr. 48, 21-27.

Béline F., Martinez J., Chadwick D., Guiziou F., Coste C.M. (1999) Factors affecting nitrogen transformations and related nitrous oxide emissions from aerobically treated piggery slurry, J. Agr. Eng. Res. 73, 235-243.

Béline F., Martinez J. (2002) Nitrogen transformations during biological aerobic treatment of pig slurry: effect of intermittent aeration on nitrous oxide emissions, Bioresource Technol. 83, 225-228.

Berg W., Brunsch R., Pazsiczki I. (2006) Greenhouse gas emissions from covered slurry compared with uncovered during storage, Agr. Ecosyst. Environ. 112, 129-134.

Berntsen J., Grant R., Olesen J.E., Kristensen I.S., Vinther F.P., Molgaard J.P., Petersen B.M. (2006) Nitrogen cycling in organic farming systems with rotational grass-clover and arable crops, Soil Use Manage. 22, 197-208.

Berry P.M., Sylvester-Bradley R., Philipps L., Hatch D.J., Cuttle S.P., Rayns F.W., Gosling P. (2002) Is the productivity of organic farms restricted by the supply of available nitrogen? Soil Use Manage. 18, 248-255.

Boadi D., Benchaar C., Chiquette J., Masse D. (2004) Mitigation strategies to reduce enteric methane emissions from dairy cows: Update review, Can. J. Anim. Sci. 84, 319-335.

Borjesson P., Berglund M. (2006) Environmental systems analysis of biogas systems - Part 1: Fuel-cycle emissions, Biomass Bioenerg. 30, $469-485$.

Brink C., Kroeze C., Klimont Z. (2001) Ammonia abatement and its impact on emissions of nitrous oxide and methane - Part 2: application for Europe, Atmos. Environ. 35, 6313-6325.

Brunschwig P., Lamy J.M. (2006) Production à la ferme d'huile végétale et de tourteaux : possibilités et conséquences, Fourrages 187, 329342 .

Bussink D.W., Oenema O. (1998) Ammonia volatilization from dairy farming systems in temperate areas: a review, Nutr. Cycl. Agroecosyst. 51, 19-33. 
Carter M.S., Ambus P. (2006) Biologically fixed $\mathrm{N}_{2}$ as a source for $\mathrm{N}_{2} \mathrm{O}$ production in a grass-clover mixture, measured by N-15(2), Nutr. Cycl. Agroecosyst. 74, 13-26.

Ceotto E., Borrelli L., Marchetti R., Tomasoni C. (2006) Effect of integrated forage rotation and manure management systems on soil carbon storage, in: Ramiran International Conference: Technology for recycling of manure and organic residues in a whole-farm perspective, DIAS, pp. 29-32.

Chadwick D.R. (2005) Emissions of ammonia, nitrous oxide and methane from cattle manure heaps: effect of compaction and covering, Atmos. Environ. 39, 787-799.

Chadwick D.R., Sneath R.W., Phillips V.R., Pain B.F. (1999) A UK inventory of nitrous oxide emissions from farmed livestock, Atmos. Environ. 33, 3345-3354.

Chapuis-Lardy L., Wrage N., Metay A., Chottes J.L., Bernouxs M. (2007) Soils, a sink for $\mathrm{N}_{2} \mathrm{O}$ ? A review, Global Change Biol. 13, 1-17.

Christopher S.F., Lal R. (2007) Nitrogen management affects carbon sequestration in North American cropland soils, Crit. Rev. Plant Sci. $26,45-64$.

Clemens J., Ahlgrimm H.J. (2001) Greenhouse gases from animal husbandry: mitigation options, Nutr. Cycl. Agroecosyst. 60, 287-300.

Clemens J., Trimborn M., Weiland P., Amon B. (2006) Mitigation of greenhouse gas emissions by anaerobic digestion of cattle slurry, Agr. Ecosyst. Environ. 112, 171-177.

Couvreur J.-P. (2006) Quelques leviers pour maîtriser la consommation d'énergie et optimiser la mécanisation de l'exploitation, Fourrages $187,301-310$.

Dalgaard T., Heidmann T., Mogensen L. (2002) Potential N-losses in three scenarios for conversion to organic farming in a local area of Denmark, Eur. J. Agron. 16, 207-217.

David C., Jeuffroy M.H., Laurent F., Mangin M., Meynard J.M. (2005) The assessment of Azodyn-Org model for managing nitrogen fertilization of organic winter wheat, Eur. J. Agron. 23, 225-242.

de Klein C.A.M., Eckard R.J. (2008) Targeted technologies for nitrous oxide abatement from animal agriculture, Aust. J. Exp. Agr. 48, 14-20.

Di H.J., Cameron K.C. (2002) Nitrate leaching in temperate agroecosystems: sources, factors and mitigating strategies, Nutr. Cycl. Agroecosyst. 64, 237-256.

Dyer J.A., Desjardins R.L. (2003) Simulated farm fieldwork, energy consumption and related greenhouse gas emissions in Canada, Biosyst. Eng. 85, 503-513.

Eriksen J., Askegaard M., Kristensen K. (1999) Nitrate leaching in an organic dairy/crop rotation as affected by organic manure type, livestock density and crop, Soil Use Manage. 15, 176-182.

Eriksen J., Pedersen L., Jorgensen J.R. (2006) Nitrate leaching and breadmaking quality of spring wheat following cultivation of different grasslands, Agr. Ecosyst. Environ. 116, 165-175.

Eriksen J., Vinther F.P., Soegaard K. (2004) Nitrate leaching and N-2fixation in grasslands of different composition, age and management, J. Agr. Sci. 142, 141-151.

EU (1991) Council Regulation No. 2092/1991 of 24 June 1991, Off. J. Eur. Communities L198, 1-5.

EU (1999) Council Regulation No. 1804/1999 of 19 July 1999, Off. J. Eur. Communities L222, 1-28.

EU (2006) Council Regulation No. 1791/2006 of 20 November 2006, Off. J. Eur. Communities L363, 1-80.

Ferm M. (1998) Atmospheric ammonia and ammonium transport in Europe and critical loads: a review, Nutr. Cycl. Agroecosyst. 51, $5-17$.
Ferm M., Kasimir-Klemedtsson A., Weslien P., Klemedtsson L. (1999) Emission of $\mathrm{NH}_{3}$ and $\mathrm{N}_{2} \mathrm{O}$ after spreading of pig slurry by broadcasting or band spreading, Soil Use Manage. 15, 27-33.

Filipovic D., Kosutic S., Gospodaric Z., Zimmer R., Banaj D. (2006) The possibilities of fuel savings and the reduction of $\mathrm{CO}_{2}$ emissions in the soil tillage in Croatia, Agr. Ecosyst. Environ. 115, 290-294.

Flessa H., Beese F. (2000) Laboratory estimates of trace gas emissions following surface application and injection of cattle slurry, J. Environ. Qual. 29, 262-268.

Flessa H., Ruser R., Dorsch P., Kamp T., Jimenez M.A., Munch J.C., Beese F. (2002) Integrated evaluation of greenhouse gas emissions $\left(\mathrm{CO}_{2}, \mathrm{CH}_{4}, \mathrm{~N}_{2} \mathrm{O}\right)$ from two farming systems in southern Germany, Agr. Ecosyst. Environ. 91, 175-189.

Foereid B., Hogh-Jensen H. (2004) Carbon sequestration potential of organic agriculture in northern Europe - a modelling approach, Nutr. Cycl. Agroecosyst. 68, 13-24.

Fontaine S., Bardoux G., Abbadie L., Mariotti A. (2004) Carbon input to soil may decrease soil carbon content, Ecol. Lett. 7, 314-320.

Forster P., Ramaswamy V., Artaxo P., Berntsen T., Betts R., Fahey D.W., Haywood J., Lean J., Lowe D.C., Myhre G., Nganga J., Prinn R., Raga G., Schulz M., Van Dorland R. (2007) Changes in Atmospheric Constituents and in Radiative Forcing, in: Solomon S., Qin D., Manning M., Chen Z., Marquis M., Averyt K.B., Tignor M., Miller H.L. (Eds.), Climate Change 2007: The Physical Science Basis, Contribution of Working Group I to the Fourth Assessment Report of the Intergovernmental Panel on Climate Change. Cambridge University Press, Cambridge, United Kingdom and New York, NY, USA.

Freibauer A., Rounsevell M.D.A., Smith P., Verhagen J. (2004) Carbon sequestration in the agricultural soils of Europe, Geoderma 122, 123.

Gibbs P.A., Parkinson R.J., Misselbrook T.H., Burchett S. (2002) Environmental impacts of cattle manure composting, in: Microbiology of Composting, Springer-Verlag Berlin, Berlin, pp. 445-456.

Gregorich E.G., Rochette P., VandenBygaart A.J., Angers D.A. (2005) Greenhouse gas contributions of agricultural soils and potential mitigation practices in Eastern Canada, Soil Till. Res. 83, 53-72.

Guarino A., Fabbri C., Brambilla M., Valli L., Navarotto P. (2006) Evaluation of simplified covering systems to reduce gaseous emissions from livestock manure storage, Trans. ASABE 49, 737-747.

Hansen S. (1996) Effects of manure treatment and soil compaction on plant production of a dairy farm system converting to organic farming practice, Agr. Ecosyst. Environ. 56, 173-186.

Hansen M.N., Sommer S.G., Henriksen K. (2002) Methane emissions from livestock manure - effects of storage conditions and climate, in: Petersen S., Olesen J. (Eds.), GHG inventories for agriculture in the nordic countries. DIAS (Danish Institute of Agricultural Science), Helsingor, Denmark, pp. 45-53.

Häring A.M. (2003) Organic dairy farms in the EU: production systems, economics and future development, Livest. Prod. Sci. 80, 89-97.

Hays M.D., Fine P.M., Geron C.D., Kleeman M.J., Gullett B.K. (2005) Open burning of agricultural biomass: Physical and chemical properties of particle-phase emissions, Atmos. Environ. 39, 6747-6764.

Hensen A., Groot T.T., van den Bulk W.C.M., Vermeulen A.T., Olesen J.E., Schelde K. (2006) Dairy farm $\mathrm{CH}_{4}$ and $\mathrm{N}_{2} \mathrm{O}$ emissions, from one square metre to the full farm scale, Agr. Ecosyst. Environ. 112, $146-152$.

Hindrichsen I.K., Wettstein H.R., Machmuller A., Kreuzer M. (2006) Methane emission, nutrient degradation and nitrogen turnover in dairy cows and their slurry at different milk production scenarios 
with and without concentrate supplementation, Agr. Ecosyst. Environ. 113, 150-161.

Holland J.M. (2004) The environmental consequences of adopting conservation tillage in Europe: reviewing the evidence, Agr. Ecosyst. Environ. 103, 1-25.

Hu S., Grunwald N.J., van Bruggen A.H.C., Gamble G.R., Drinkwater L.E., Shennan C., Demment M.W. (1997) Short-term effects of cover crop incroporation on soil carbon pools and nitrogen availability, Soil Sci. Soc. Am. J. 61, 901-911.

Husted S. (1994) Seasonal variation in methane emission from stored slurry and solid manures, J. Environ. Qual. 23, 585-592.

INRA (2002) Stocker du carbone dans les sols agricoles en France? Expertise scientifique collective, in: Arrouays D., Balesdent J., Germon J.C., Jayet P.A., Soussana J.F., Stengel P. (Eds.), Institut National de la Recherche Agronomique (INRA), Paris, p. 332.

IPCC (2007) Climate Change 2007: Impacts, Adaptation and Vulnerability. Contribution of working group II to the Fourth Assessment Report of the Intergovernmental Panel on Climate Change, in: Parry M.L., Canziani O.F., Palutikof J.P., Van der Linden P.J., Hanson C.E. (Eds.), Cambridge University Press, Cambridge, United Kingdom and New York, NY, USA.

Johnson J.M.-F., Franzluebbers A.J., Weyers S.L., Reicosky D.C. (2007) Agricultural opportunities to mitigate greenhouse gas emissions, Environ. Pollut. 150, 107-124.

Kebreab E., Clark K., Wagner-Riddle C., France J. (2006) Methane and nitrous oxide emissions from Canadian animal agriculture: A review, Can. J. Anim. Sci. 86, 135-158.

Keppler F., Hamilton J.T.G., Brass M., Rockmann T. (2006) Methane emissions from terrestrial plants under aerobic conditions, Nature 439, 187-191.

Kern J.S., Johnson M.G. (1993) Conservation tillage impacts on national soil and atmospheric carbon levels, Soil Sci. Soc. Am. J. 57, 200210.

Kirchmann H., Bernal M.P. (1997) Organic waste treatment and C stabilization efficiency, Soil Biol. Biochem. 29, 1747-1753.

Kuikman P.J., Velthof G.L., Oenema O. (2004) Controlling nitrous oxide emissions from agriculture: experience from The Netherlands, in: Hatch D.J., Chadwick D.R., Jarvis S.C., Roker J.A. (Eds.), Controlling nitrogen flows and losses, 12th Nitrogen Workshop, Wageningen Academic Publishers, University of Exeter, UK.

Kulling D.R., Menzi H., Sutter F., Lischer P., Kreuzer M. (2003) Ammonia, nitrous oxide and methane emissions from differently stored dairy manure derived from grass- and hay-based rations, Nutr. Cycl. Agroecosyst. 65, 13-22.

Lal R. (2004a) Agricultural activities and the global carbon cycle, Nutr. Cycl. Agroecosyst. 70, 103-116.

Lal R. (2004b) Soil carbon sequestration to mitigate climate change, Geoderma 123, 1-22.

Le Mer J., Roger P. (2001) Production, oxidation, emission and consumption of methane by soils: A review, Eur. J. Soil Biol. 37, 25-50.

Ledgard S.F. (2001) Nitrogen cycling in low input legume-based agriculture, with emphasis on legume/grass pastures, Plant Soil 228 , $43-59$.

Ledgard S., Steele K.W. (1992) Biological nitrogen fixation in mixed legume/grass pastures, Plant Soil 141, 137-153.

Lovett D.K., Shalloo L., Dillon P., O’Mara F.P. (2006) A systems approach to quantify greenhouse gas fluxes from pastoral dairy production as affected by management regime, Agr. Syst. 88, 156-179.

Malgeryd J. (1998) Technical measures to reduce ammonia losses after spreading of animal manure, Nutr. Cycl. Agroecosyst. 51, 51-57.
Marshall E.J.P., Moonen A.C. (2002) Field margins in northern Europe: their functions and interactions with agriculture, Agr. Ecosyst. Environ. 89, 5-21.

Martin C., Morgavi D., Doreau M., Jouany J.P. (2006) Comment réduire la production de méthane chez les ruminants? Fourrages 187, 283300 .

Martin C., Rouel J., Jouany J.P., Doreau M., Chilliard Y. (2008) Methane output and diet digestibility in response to feeding dairy cows crude linseed, extruded linseed, or linseed oil, J. Anim. Sci. 2642-2650.

Martinez J., Guiziou F., Peu P., Gueutier V. (2003) Influence of treatment techniques for pig slurry on methane emissions during subsequent storage, Biosyst. Eng. 85, 347-354.

Mathieu O., Leveque J., Henault C., Milloux M.J., Bizouard F., Andreux F. (2006) Emissions and spatial variability of $\mathrm{N}_{2} \mathrm{O}, \mathrm{N}_{2}$ and nitrous oxide mole fraction at the field scale, revealed with $\mathrm{N}-15$ isotopic techniques, Soil Biol. Biochem. 38, 941-951.

McAllister T.A., Okine E.K., Mathison G.W., Cheng K.J. (1996) Dietary, environmental and microbiological aspects of methane production in ruminants, Can. J. Anim. Sci. 76, 231-243.

McCaughey W.P., Wittenberg K., Corrigan D. (1997) Methane production by steers on pasture, Can. J. Anim. Sci. 77, 519-524.

McCaughey W.P., Wittenberg K., Corrigan D. (1999) Impact of pasture type on methane production by lactating beef cows, Can. J. Anim. Sci. 79, 221-226.

McGinn S.M. (2006) Measuring greenhouse gas emissions from point sources in agriculture, Can. J. Soil Sci. 86, 355-371.

McNeill A.M., Eriksen J., Bergstrom L., Smith K.A., Marstorp H., Kirchmann H., Nilsson I. (2005) Nitrogen and sulphur management: challenges for organic sources in temperate agricultural systems, Soil Use Manage. 21, 82-93.

Mills J.A.N., Dijkstra J., Bannink A., Cammell S.B., Kebreab E., France J. (2001) A mechanistic model of whole-tract digestion and methanogenesis in the lactating dairy cow: Model development, evaluation, and application, J. Anim. Sci. 79, 1584-1597.

Misselbrook T.H., Brookman S.K.E., Smith K.A., Cumby T., Williams A.G., McCrory D.F. (2005) Crusting of stored dairy slurry to abate ammonia emissions: Pilot-scale studies, J. Environ. Qual. 34, 411419.

Monteny G.J., Bannink A., Chadwick D. (2006) Greenhouse gas abatement strategies for animal husbandry, Agr. Ecosyst. Environ. 112, $163-170$.

Monteny G.J., Groenestein C.M., Hilhorst M.A. (2001) Interactions and coupling between emissions of methane and nitrous oxide from animal husbandry, Nutr. Cycl. Agroecosyst. 60, 123-132.

Morvan T., Nicolardot B., Pean L. (2006) Biochemical composition and kinetics of $\mathrm{C}$ and $\mathrm{N}$ mineralization of animal wastes: a typological approach, Biol. Fert. Soils 42, 513-522.

Mosier A., Kroeze C., Nevison C., Oenema O., Seitzinger S., van Cleemput O. (1998) Closing the global $\mathrm{N}_{2} \mathrm{O}$ budget: nitrous oxide emissions through the agricultural nitrogen cycle, Nutr. Cycl. Agroecosyst. 52, 225-248.

Mosimann E., Suter D. (2003) Autonomie en protéines et environnement: le compromis helvétique, Fourrages 175, 333-345.

Mustin M. (1987) Le compost - Gestion de la matière organique, Dubusc F., $954 \mathrm{p}$.

Nicholas P.K., Padel S., Cuttle S.P., Fowler S.M., Hovi M., Lampkin N.H., Weller R.F. (2004) Organic dairy production: a review, Biol. Agric. Hortic. 22, 1-58.

Oenema O., Velthof G., Kuikman P. (2001) Technical and policy aspects of strategies to decrease greenhouse gas emissions from agriculture, Nutr. Cycl. Agroecosyst. 60, 301-315. 
Oenema O., Velthof G.L., Yamulki S., Jarvis S.C. (1997) Nitrous oxide emissions from grazed grassland, Soil Use Manage. 13, 288-295.

Oenema O., Wrage N., Velthof G.L., van Groenigen J.W., Dolfing J., Kuikman P.J. (2005) Trends in global nitrous oxide emissions from animal production systems, Nutr. Cycl. Agroecosyst. 72, 51-65.

Olesen J.E., Schelde K., Weiske A., Weisbjerg M.R., Asman W.A.H., Djurhuus J. (2006) Modelling greenhouse gas emissions from European conventional and organic dairy farms, Agr. Ecosyst. Environ. 112, 207-220.

Peigne J., Girardin P. (2004) Environmental impacts of farm-scale composting practices, Water Air Soil Pollut. 153, 45-68.

Petersen S.O. (1999) Nitrous oxide emissions from manure and inorganic fertilizers applied to spring barley, J. Environ. Qual. 28, 1610-1618.

Petersen S.O., Amon B., Gattinger A. (2005) Methane oxidation in slurry storage surface crusts, J. Environ. Qual. 34, 455-461.

Petersen S.O., Regina K., Pollinger A., Rigler E., Valli L., Yamulki S., Esala M., Fabbri C., Syvasalo E., Vinther F.P. (2006) Nitrous oxide emissions from organic and conventional crop rotations in five European countries, Agr. Ecosyst. Environ. 112, 200-206.

Pflimlin A., Kempf M. (2002) Trends of the organic dairy industry in some European countries, $9^{\text {es }}$ Rencontres autour des Recherches sur les Ruminants, Paris, France, 4-5 decembre 2002, pp. 215-218.

Pinares-Patino C.S., Baumont R., Martin C. (2003) Methane emissions by Charolais cows grazing a monospecific pasture of timothy at four stages of maturity, Can. J. Anim. Sci. 83, 769-777.

Pinares-Patino C.S., D’Hour P., Jouany J.-P., Martin C. (2007) Effects of stocking rate on methane and carbon dioxide emissions from grazing cattle, Agr. Ecosyst. Environ. 121, 30-46.

Rasmussen P.E., Douglas C.L., Collins H.P., Albrecht S.L. (1998) Longterm cropping system on mineralizable nitrogen in soil, Soil Biol. Biochem. 30, 1829-1837.

Rees R.M., Bingham I.J., Baddeley J.A., Watson C.A. (2005) The role of plants and land management in sequestering soil carbon in temperate arable and grassland ecosystems, Geoderma 128, 130-154.

Reicosky D.C., Reeves D.W., Prior S.A., Runion G.B., Rogers H.H., Raper R.L. (1999) Effects of residue management and controlled traffic on carbon dioxide and water loss, Soil Till. Res. 52, 153165.

Rochette P., Janzen H.H. (2005) Towards a revised coefficient for estimating $\mathrm{N}_{2} \mathrm{O}$ emissions from legumes, Nutr. Cycl. Agroecosyst. 73, 171-179.

Rubaek G.H., Henriksen K., Petersen J., Rasmussen B., Sommer S.G. (1996) Effects of application technique and anaerobic digestion on gaseous nitrogen loss from animal slurry applied to ryegrass (Lolium perenne), J. Agr. Sci. 126, 481-492.

Saggar S., Bolan N.S., Bhandral R., Hedley C.B., Luo J. (2004) A review of emissions of methane, ammonia, and nitrous oxide from animal excreta deposition and farm effluent application in grazed pastures, New Zeal J. Agr. Res. 47, 513-544.

Schils R.L.M., Olesen J.E., del Prado A., Soussana J.F. (2007) A review of farm level modelling approaches for mitigating greenhouse gas emissions from ruminant livestock systems, Livest. Sci. 112, 240251.

Schils R.L.M., Verhagen A., Aarts H.F.M., Kuikman P.J., Sebek L.B.J. (2006) Effect of improved nitrogen management on greenhouse gas emissions from intensive dairy systems in the Netherlands, Global Change Biol. 12, 382-391.

Schils R.L.M., Verhagen A., Aarts H.F.M., Sebek L.B.J. (2005) A farm level approach to define successful mitigation strategies for GHG emissions from ruminant livestock systems, Nutr. Cycl. Agroecosyst. 71, 163-175.
Shepherd M.A. (2000) The environmental implications of manure use in organic farming systems, ADAS, p. 20.

Shepherd M., Pearce B., Philipps L., Cuttle S., Bhogal A., Costigan P., Unwin R. (2003) An assessment of the environmental impacts of organic farming, DEFRA, p. 80.

Six J., Ogle S.M., Breidt F.J., Conant R.T., Mosier A.R., Paustian K. (2004) The potential to mitigate global warming with no-tillage management is only realized when practised in the long term, Global Change Biol. 10, 155-160.

Smith P. (2004) Carbon sequestration in croplands: the potential in Europe and the global context, Eur. J. Agron. 20, 229-236.

Smith K.A., Conen F. (2004) Impacts of land management on fluxes of trace greenhouse gases, Soil Use Manage. 20, 255-263.

Smith P., Goulding K.W., Smith K.A., Powlson D.S., Smith J.U., Falloon P., Coleman K. (2001) Enhancing the carbon sink in European agricultural soils: including trace gas fluxes in estimates of carbon mitigation potential, Nutr. Cycl. Agroecosyst. 60, 237-252.

Smith P., Martino D., Cai Z.C., Gwary D., Janzen H., Kumar P., McCarl B., Ogle S., O’Mara F., Rice C., Scholes B., Sirotenko O., Howden M., McAllister T., Pan G.X., Romanenkov V., Schneider U., Towprayoon S. (2007) Policy and technological constraints to implementation of greenhouse gas mitigation options in agriculture, Agr. Ecosyst. Environ. 118, 6-28.

Smith P., Martino D., Cai Z., Gwary D., Janzen H., Kumar P., McCarl B., Ogle S., O’Mara F., Rice C., Scholes B., Sirotenko O., Howden M., McAllister T., Pan G.X., Romanenkov V., Schneider U., Towprayoon S., Wattenbach M., Smith J. (2008) Greenhouse gas mitigation in agriculture, Philos. T. Roy. Soc. B-Biol. Sci. 363, 789813.

Smith P., Milne R., Powlson D.S., Smith J.U., Falloon P., Coleman K. (2000) Revised estimates of the carbon mitigation potential of UK agricultural land, Soil Use Manage. 16, 293-295.

Smith P., Powlson D.S., Glendining M.J., Smith J.U. (1997) Potential for carbon sequestration in European soils: preliminary estimates for five scenarios using results from long-term experiments, Global Change Biol. 3, 67-79.

Sneath R.W., Beline F., Hilhorst M.A., Peu P. (2006) Monitoring GHG from manure stores on organic and conventional dairy farms, Agr. Ecosyst. Environ. 112, 122-128.

Sommer S.G. (2001) Effect of composting on nutrient loss and nitrogen availability of cattle deep litter, Eur. J. Agron. 14, 123-133.

Sommer S.G., Hutchings N.J. (2001) Ammonia emission from field applied manure and its reduction - invited paper, Eur. J. Agron. 15, $1-15$.

Sommer S.G., Olesen J.E. (2000) Modelling ammonia emission from animal slurry applied with trail hoses to cereals, Atmos. Environ. 34, 2361-2372.

Sommer S.G., Christensen B.T., Nielsen N.E., Schjorring J.K. (1993) Ammonia volatilization during storage of cattle and pig slurry: effect of surface cover, J. Agr. Sci. 121, 63-71.

Sommer S.G., Petersen S.O., Sogaard H.T. (2000) Greenhouse gas emission from stored livestock slurry, J. Environ. Qual. 29, 744-751.

Sorensen P., Weisbjerg M.R., Lund P. (2003) Dietary effects on the composition and plant utilization of nitrogen in dairy cattle manure, J. Agr. Sci. 141, 79-91.

Soussana J.F., Allard V., Pilegaard K., Ambus P., Amman C., Campbell C., Ceschia E., Clifton-Brown J., Czobel S., Domingues R., Flechard C., Fuhrer J., Hensen A., Horvath L., Jones M., Kasper G., Martin C., Nagy Z., Neftel A., Raschi A., Baronti S., Rees R.M., Skiba U., Stefani P., Manca G., Sutton M., Tuba Z., Valentini R. (2007) Full accounting of the greenhouse gas $\left(\mathrm{CO}_{2}, \mathrm{~N}_{2} \mathrm{O}, \mathrm{CH}_{4}\right)$ budget of nine European grassland sites, Agr. Ecosyst. Environ. $121,121-134$. 
Soussana J.F., Loiseau P., Vuichard N., Ceschia E., Balesdent J., Chevallier T., Arrouays D. (2004) Carbon cycling and sequestration opportunities in temperate grasslands, Soil Use Manage. 20, 219-230.

Steinfeld H., Gerber P., Wassenaar T., Castel V., Rosales M., de Haan C. (2006) Livestock's long shadow - environmental issues and options. in: FAO (Ed.), FAO, Rome, p. 390.

Steinshamn H., Thuen E., Bleken M.A., Brenoe U.T., Ekerholt G., Yri C. (2004) Utilization of nitrogen (N) and phosphorus (P) in an organic dairy farming system in Norway, Agr. Ecosyst. Environ.104, 509522 .

Stockdale E.A., Rees R.M. (1995) Release of nitrogen from plant and animal residues and consequent plant uptake efficiency, Biol. Agric. Hortic. 11, 229-245.

Stockdale E.A., Lampkin N.H., Hovi M., Keatinge R., Lennartsson E.K.M., Macdonald D.W., Padel S., Tattersall F.H., Wolfe M.S., Watson C.A. (2001) Agronomic and environmental implications of organic farming systems, Adv. Agron. 70, 261-327.

Stolze M., Piorr A., Haring A., Dabbert S. (2000) The Environmental Impacts of Organic Farming in Europe, in: Dabbert S., Lampkin N., Michelsen J., Nieberg H., Zanoli R. (Eds.), Organic Farming in Europe: Economics and Policy. Dabbert S. - University of Hohenheim, Stuttgart-Hohenheim, p. 127.

Stopes C., Lord E.I., Philipps L., Woodward L. (2002) Nitrate leaching from organic farms and conventional farms following best practice, Soil Use Manage. 18, 256-263.

Sutton M.A., Milford C., Nemitz E., Theobald M.R., Hill P.W., Fowler D., Schjoerring J.K., Mattsson M.E., Nielsen K.H., Husted S., Erisman J.W., Otjes R., Hensen A., Mosquera J., Cellier P., Loubet B., David M., Genermont S., Neftel A., Blatter A., Herrmann B., Jones S.K., Horvath L., Fuhrer E.C., Mantzanas K., Koukoura Z., Gallagher M., Williams P., Flynn M., Riedo M. (2001) Biosphere-atmosphere interactions of ammonia with grasslands: Experimental strategy and results from a new European initiative, Plant Soil 228, 131-145.

Sutton M.A., Pitcairn C.E.R., Fowler D. (1993) The exchange of ammonia between the atmosphere and plant communities, Adv. Ecol. Res. 24, 301-393.

Syväsalo E., Regina K., Turtola E., Lemola R., Esala M. (2006) Fluxes of nitrous oxide and methane, and nitrogen leaching from organically and conventionally cultivated sandy soil in western Finland, Agr. Ecosyst. Environ. 113, 342-348.

Tavendale M.H., Lane G.A., Schreurs N.M., Fraser K., Meagher L.P. (2005) The effects of condensed tannins from Dorycnium rectum on skatole and indole ruminal biogenesis for grazing sheep, Aust. J. Agr. Res. 56, 1331-1337.

Theobald M.R., Milford C., Hargreaves K.J., Sheppard L.J., Nemitz E., Tang Y.S., Phillips V.R., Sneath R., McCartney L., Harvey F.J., Leith I.D., Cape J.N., Fowler D., Sutton M.A. (2002) Potential for ammonia recapture by farm woodlands: design and application of a new experimental facility, in: Optimizing nitrogen management in food and energy production and environmental protection, 2nd International Nitrogen Conference, Potomac, Maryland, USA, 1418 October 2001, A.A. Balkema Publishers, Lisse Netherlands.

Vaarst M., Padel S., Hovi M., Younie D., Sundrum A. (2005) Sustaining animal health and food safety in European organic livestock farming, Livest. Prod. Sci. 94, 61-69.

Vellinga T.V., van den Pol-van Dasselaar A., Kuikman P.J. (2004) The impact of grassland ploughing on $\mathrm{CO}_{2}$ and $\mathrm{N}_{2} \mathrm{O}$ emissions in the Netherlands, Nutr. Cycl. Agroecosyst. 70, 33-45.
Velthof G.L., van Beusichem M.L., Oenema O. (1998) Mitigation of nitrous oxide emission from dairy farming systems, Environ. Pollut. $102,173-178$.

Velthof G.L., Kuikman P.J., Oenema O. (2002) Nitrous oxide emission from soils amended with crop residues, Nutr. Cycl. Agroecosyst. $62,249-261$.

Vleeshouwers L.M., Verhagen A. (2002) Carbon emission and sequestration by agricultural land use: a model study for Europe, Global Change Biol. 8, 519-530.

Watson C.A., Atkinson D., Gosling P., Jackson L.R., Rayns F.W. (2002) Managing soil fertility in organic farming systems, Soil Use Manage. 18, 239-247.

Watson C.A., Oborn I., Eriksen J., Edwards A.C. (2005) Perspectives on nutrient management in mixed farming systems, Soil Use Manage. $21,132-140$.

Webb J., Chadwick D., Ellis S. (2004) Emissions of ammonia and nitrous oxide following incorporation into the soil of farmyard manures stored at different densities, Nutr. Cycl. Agroecosyst. 70, 67-76.

Webb J., Menzi H., Pain B.F., Misselbrook T.H., Dammgen U., Hendriks H., Dohler H. (2005) Managing ammonia emissions from livestock production in Europe, Environ. Pollut. 135, 399-406.

Weiske A., Vabitsch A., Olesen J.E., Schelde K., Michel J., Friedrich R., Kaltschmitt M. (2006) Mitigation of greenhouse gas emissions in European conventional and organic dairy farming, Agr. Ecosyst. Environ. 112, 221-232.

Weller R.F. (2002) A comparison of two systems of organic milk production, in: Kyriazakis Z. (Ed.), Proceedings of Organic Meat and Milk for Ruminants, EAAP Publication, Athens, pp. 111-116.

West T.O., Post W.M. (2002) Soil organic carbon sequestration rates by tillage and crop rotation: A global data analysis, Soil Sci. Soc. Am. J. 66, 1930-1946.

West T.O., Six J. (2007) Considering the influence of sequestration duration and carbon saturation on estimates of soil carbon capacity, Climatic Change 80, 25-41.

WHO (2004) Health aspects of air pollution: Results from the WHO project systematic review of health aspects of air pollution in Europe, p. 24.

Woodward S.L., Waghorn G.C., Lassey K.R., Laboyrie P.G. (2002) Does feeding sulla (Hedysarum coronarium) reduce methane emissions from dairy cows? Proc. N.Z. Soc. Anim. Prod. 62, 227-230.

Wright A.L., Dou F., Hons F.M. (2007) Crop species and tillage effects on carbon sequestration in subsurface soil, Soil Sci. 172, 124-131.

Wulf S., Maeting M., Clemens J. (2002a) Application technique and slurry co-fermentation effects on ammonia, nitrous oxide, and methane emissions after spreading: II. Greenhouse gas emissions, J. Environ. Qual. 31, 1795-1801.

Wulf S., Maeting M., Clemens J. (2002b) Application technique and slurry co-fermentation effects on ammonia, nitrous oxide, and methane emissions after spreading: I. Ammonia volatilization, J. Environ. Qual. 31, 1789-1794.

Yamulki S. (2006) Effect of straw addition on nitrous oxide and methane emissions from stored farmyard manures, Agr. Ecosyst. Environ. $112,140-145$. 